ArgOnational laboratory

\title{
Life-Cycle Assessment of Corn-Based Butanol as a Potential Transportation Fuel
}

Energy Systems Division 


\begin{abstract}
About Argonne National Laboratory
Argonne is a U.S. Department of Energy laboratory managed by UChicago Argonne, LLC under contract DE-AC02-06CH11357. The Laboratory's main facility is outside Chicago, at 9700 South Cass Avenue, Argonne, Illinois 60439. For information about Argonne, see www.anl.gov.
\end{abstract}

\title{
Availability of This Report
}

This report is available, at no cost, at http://www.osti.gov/bridge. It is also available on paper to the U.S. Department of Energy and its contractors, for a processing fee, from:

U.S. Department of Energy

Office of Scientific and Technical Information

P.O. Box 62

Oak Ridge, TN 37831-0062

phone (865) 576-8401

fax (865) 576-5728

reports@adonis.osti.gov

\begin{abstract}
Disclaimer
This report was prepared as an account of work sponsored by an agency of the United States Government. Neither the United States Government nor any agency thereof, nor UChicago Argonne, LLC, nor any of their employees or officers, makes any warranty, express or implied, or assumes any legal liability or responsibility for the accuracy, completeness, or usefulness of any information, apparatus, product, or process disclosed, or represents that its use would not infringe privately owned rights. Reference herein to any specific commercial product, process, or service by trade name, trademark, manufacturer, or otherwise, does not necessarily constitute or imply its endorsement, recommendation, or favoring by the United States Government or any agency thereof. The views and opinions of document authors expressed herein do not necessarily state or reflect those of the United States Government or any agency thereof, Argonne National Laboratory, or UChicago Argonne, LLC.
\end{abstract}




\section{Life-Cycle Assessment of Corn-Based Butanol as a Potential Transportation Fuel}

by

M. Wu, M. Wang, J. Liu, and H. Huo

Center for Transportation Research, Energy Systems Division,

Argonne National Laboratory

Work supported by the

U.S. Department of Energy's FreedomCAR and Vehicle Technologies Program

(Office of Energy Efficiency and Renewable Energy)

November 2007 



\section{CONTENTS}

ACKNOWLEDGMENTS ............................................................................... vi

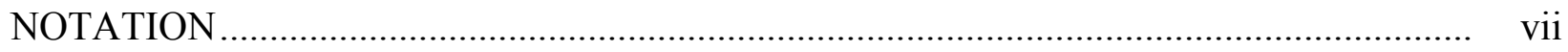

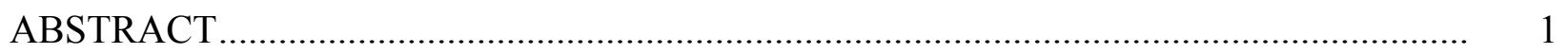

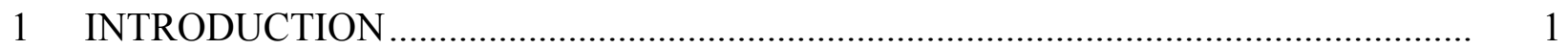

2 LCA SYSTEM BOUNDARY AND ANALYSIS SCENARIOS ............................... 5

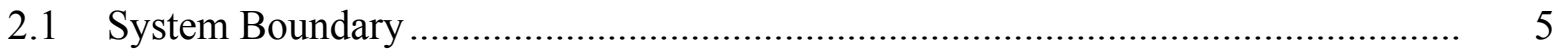

2.2 Analysis Cases ................................................................................. 6

$3 \quad$ ASPEN PLUS ${ }^{\circledR}$ SIMULATION OF THE ABE PROCESS ....................................... 9

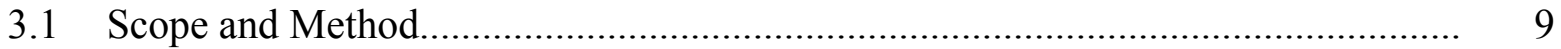

3.2 Overview of ABE Process ........................................................................ 9

3.2.1 Grain Receiving, Liquefaction, and Saccharification ............................ 10

3.2.2 Fermentation and In-Situ Gas Stripping ........................................... 11

3.2.3 Downstream Processing................................................................... 12

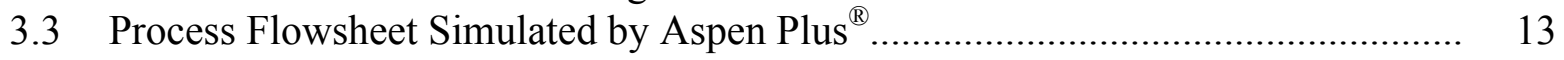

3.3.1 ABE Process Flowsheet ................................................................... 13

3.3.2 Estimate of Energy Use for Adsorbent Regeneration............................ 17

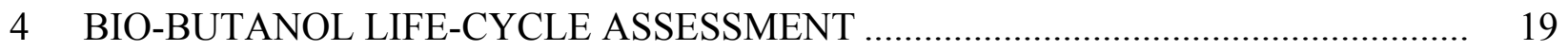

4.1 Bio-Butanol Plant Energy Requirements........................................................... 19

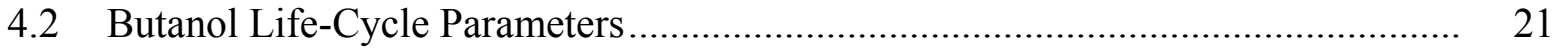

4.3 Co-Product Credit ............................................................................................ 22

4.4 Cradle-to-User Assessment of Petroleum Acetone and Displacement................... 24

4.4.1 Petroleum Acetone and Feedstocks Production...................................... 24

4.4.2 Assumptions and Data Sources..................................................... 24

4.4.3 Petroleum Acetone Displacement...................................................... 26

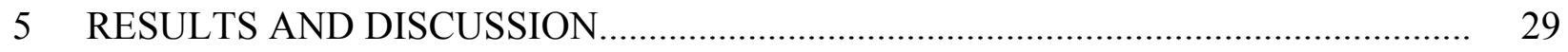

5.1 Energy Consumption and GHG Emissions.................................................. 29

5.2 Effect of Acetone Co-Product Credit................................................................. 30

5.3 Comparison of Bio-Butanol with Corn Ethanol ................................................ 32

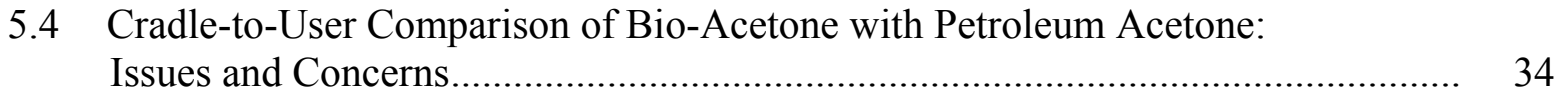

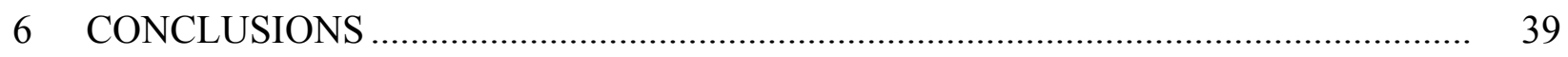




\section{CONTENTS (CONT.)}

A1 Parameters for Corn Butanol Life-Cycle Analysis .............................................. 47

A2 Parameters for Petroleum-Based Acetone Analysis .......................................... 48

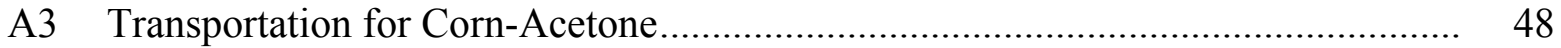

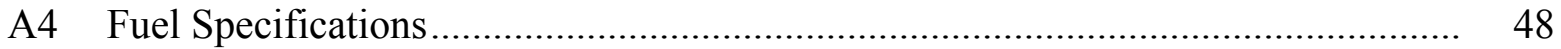

\section{FIGURES}

1 Schematic Representation of WTW Analysis System Boundaries for Butanol, Ethanol, and Gasoline...

2 Schematic for Grain Receiving, Liquefaction, and Saccharification

3 Schematic Representation of Adsorption and Adsorbent Regeneration

4 Aspen Plus ${ }^{\circledR}$ Output of the Process Flowsheet from Fermentation to Downstream Processing

5 System Boundaries for Cradle-to-User Pathway of Fossil-Based Acetone and Corn-Based Acetone.

6 Well-to-Pump Fossil Energy Breakdown for Bio-Butanol and Corn Ethanol Compared with Gasoline, Using Different Co-Product Allocation Methods....

7 Breakdown of Fossil Energy Use in Various Stages of Fuel Life Cycle for Corn-Based Butanol

8 Life-Cycle GHG Emissions of Bio-Butanol and Ethanol Compared with Gasoline, Using Different Co-Product Allocation Methods

9 Life-Cycle GHG Emission Breakdown for Bio-Butanol and Ethanol.

10 Fossil Energy Use Based on the Production of Bio-Acetone Compared with Fossil Energy Use Based on the Production of Petroleum.

11 Fossil Energy Consumption Breakdown for (a) Bio-Acetone and (b) Petroleum Acetone. 


\section{FIGURES (CONT.)}

12 GHG Emissions Generated or Avoided by Bio-Acetone Production

Compared with Petroleum Acetone Production

\section{TABLES}

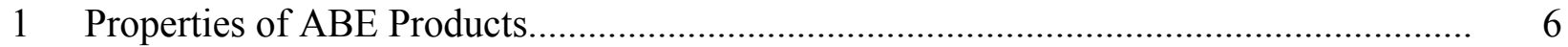

2 Main Input Parameters for Fermentation and Gas Stripping for

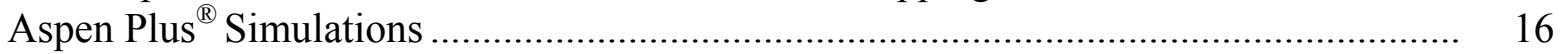

3 Material Balance of Bio-Butanol Plant ………...................................................... 16

4 Yields of Acetone, Butanol, and Ethanol from Bio-Butanol Plant .................................. 17

$5 \quad$ Process Fuel Use for ABE Fermentation and Downstream Processing ............................ 17

6 Parameters for Calculating Energy Use for Adsorbent Regeneration............................... 18

$7 \quad$ Thermal Energy Requirements in Bio-Butanol Plant......................................................... 20

8 Electricity Consumption in Bio-Butanol Plants ......................................................... 20

9 GREET Input Parameters for Corn Butanol WTW Analysis: Corn Farming, Transportation of Corn and Butanol, and Vehicle Operation........................................... 21

10 U.S. Average Electricity Generation Mix Used in this Study ......................................... 22

11 Co-Product Energy Partitioning by Energy Allocation..................................................... 23

12 Assumptions and Data Sources of Cradle-to-User Petroleum Acetone ............................ 25

13 Low-Heating-Value Comparison for this Study ........................................................ 26

14 Acetone, Butanol, and Ethanol Outputs from Corn Compared with Ethanol from Conventional Corn Mills .......................................................................................... 33

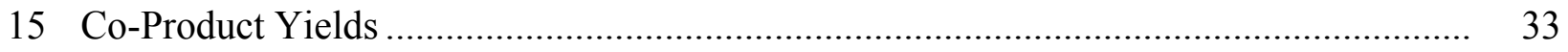

16 Process Fuel Use in Bio-Butanol and Ethanol Production Plant...................................... 34 


\section{ACKNOWLEDGMENTS}

This work was sponsored by the U.S. Department of Energy's Office of FreedomCAR and Vehicle Technologies, which is part of the Office of Energy Efficiency and Renewable Energy. We would like to thank Professor Hans Blaschek of the University of Illinois at UrbanaChampaign and Dr. Nasib Quresh of the U.S. Department of Agriculture (USDA) Agricultural Research Service (ARS) National Center for Agricultural Utilization Research (NCAUR) for providing process data and insights on the ABE process. We also thank Andrew McAloon of USDA Economic Research Service (ERS) Eastern Regional Research Center (ERRC) for providing the corn-to-ethanol dry mill ASPEN+ model. Several experts reviewed this report: Dr. Vernel Stanciulescu of Natural Resources Canada, Dr. Robin Jenkins of DuPont, and Professor Han Blaschek of the University of Illinois at Urbana-Champaign. We deeply appreciate their input. Argonne National Laboratory is a U.S. Department of Energy laboratory managed by UChicago Argonne, LLC, under Contract No. DE-AC02-06CH11357. 


\section{NOTATION}

\begin{tabular}{|c|c|}
\hline $\mathrm{ABE}$ & acetone, butanol, and ethanol \\
\hline $\mathrm{BC}$ & biochemical \\
\hline BTX & benzene, toluene, xylene \\
\hline $\mathrm{CEH}$ & Chemical Economics Handbook \\
\hline $\mathrm{CH}_{4}$ & methane \\
\hline $\mathrm{CO}$ & carbon monoxide \\
\hline $\mathrm{CO}_{2}$ & carbon dioxide \\
\hline DDGS & distiller's dried grain with solubles \\
\hline DOE & Department of Energy \\
\hline $\begin{array}{l}\text { EIA } \\
\text { EtOH }\end{array}$ & $\begin{array}{l}\text { Energy Information Administration } \\
\text { ethanol }\end{array}$ \\
\hline GHG & greenhouse gas \\
\hline $\begin{array}{l}\text { GREET } \\
\text { GV }\end{array}$ & $\begin{array}{l}\text { Greenhouse Gases, Regulated Emissions and Energy Use in Transportation } \\
\text { gasoline vehicles }\end{array}$ \\
\hline IPCC & Intergovernmental Panel on Climate Change \\
\hline $\mathrm{K}_{2} \mathrm{O}$ & potash fertilizer \\
\hline LCA & life-cycle analysis \\
\hline LCI & life-cycle inventory \\
\hline LDV & light-duty vehicle \\
\hline LHV & low heating value \\
\hline MMGY & million gallons per year \\
\hline $\mathrm{N}$ & nitrogen \\
\hline $\mathrm{N}_{2} \mathrm{O}$ & nitrous oxide \\
\hline NG & natural gas \\
\hline $\mathrm{NO}_{\mathrm{x}}$ & nitrogen oxide \\
\hline $\mathrm{P}_{2} \mathrm{O}_{5}$ & phosphorus fertilizer \\
\hline $\mathrm{PM}_{10}$ & particulate matter with diameters smaller than 10 micrometers \\
\hline $\mathrm{PM}_{2.5}$ & particulate matter with diameters smaller than 10 micrometers \\
\hline$R \& D$ & research and development \\
\hline RTO & regenerative thermal oxidizer \\
\hline
\end{tabular}


$\mathrm{SO}_{\mathrm{x}} \quad$ sulfur oxide

USDA U.S. Department of Agriculture

VOC volatile organic compound

WTW well-to-wheels

\section{UNITS OF MEASURE}

Btu British thermal unit

bu bushel

g gram(s)

gal gallon(s)

$\mathrm{kg} \quad$ kilogram(s)

$\mathrm{kW} \quad$ kilowatt(s)

$\mathrm{kWh} \quad$ kilowatt hour(s)

L liter

lb pound(s)

MJ mega Joule

psi pounds per square inch

scf standard cubic feet

$\mathrm{wt} \% \quad$ weight percent

$\mathrm{yr} \quad$ year 


\title{
LIFE-CYCLE ASSESSMENT OF CORN-BASED BUTANOL AS A POTENTIAL TRANSPORTATION FUEL
}

\author{
by \\ May Wu, Michael Wang, Jiahong Liu, and Hong Huo
}

\begin{abstract}
Butanol produced from bio-sources (such as corn) could have attractive properties as a transportation fuel. Production of butanol through a fermentation process called acetone-butanolethanol (ABE) has been the focus of increasing research and development efforts. Advances in ABE process development in recent years have led to drastic increases in ABE productivity and yields, making butanol production worthy of evaluation for use in motor vehicles. Consequently, chemical/fuel industries have announced their intention to produce butanol from bio-based materials. The purpose of this study is to estimate the potential life-cycle energy and emission effects associated with using bio-butanol as a transportation fuel. The study employs a well-towheels analysis tool — the Greenhouse Gases, Regulated Emissions and Energy Use in Transportation (GREET) model developed at Argonne National Laboratory — and the Aspen Plus ${ }^{\circledR}$ model developed by AspenTech. The study describes the butanol production from corn, including grain processing, fermentation, gas stripping, distillation, and adsorption for products separation. The Aspen ${ }^{\circledR}$ results that we obtained for the corn-to-butanol production process provide the basis for GREET modeling to estimate life-cycle energy use and greenhouse gas emissions. The GREET model was expanded to simulate the bio-butanol life cycle, from agricultural chemical production to butanol use in motor vehicles. We then compared the results for bio-butanol with those of conventional gasoline. We also analyzed the bio-acetone that is coproduced with bio-butanol as an alternative to petroleum-based acetone. Our study shows that, while the use of corn-based butanol achieves energy benefits and reduces greenhouse gas emissions, the results are affected by the methods used to treat the acetone that is co-produced in butanol plants.
\end{abstract}

\section{INTRODUCTION}

Liquid fuel use accounts for the single largest share of petroleum oil consumption in the United States. In 2006, the United States consumed more than 20 million barrels of crude oil per day; $66 \%$ of this total was used in the transportation sector. Motor vehicles alone consumed 140 billion gallons of gasoline and 50 billion gallons of diesel in 2006. Gasoline use has increased as a result of the growth in light-duty vehicle (LDV) travel in the past 20 years. The Energy Information Administration projected that transportation fuel use will continue to grow up to $30 \%$ by 2030 (Conti 2007). 
On the petroleum supply side, the United States relies heavily on foreign oil (13.7 million barrels per day, EIA 2007). The world's most oil-rich region has become extremely unstable, which heightens energy security concerns. Furthermore, competition for petroleum oil has increased dramatically as a result of rapid economic growth in developing countries. Finally, exploration, production, and use of petroleum-based fuels generate greenhouse gas (GHG) emissions, which are the primary cause of global warming, as confirmed in a recent report prepared by the Intergovernmental Panel on Climate Change (IPCC 2007).

Considering the challenges facing the United States in its continued reliance on fossilbased fuels in the transportation sector, many researchers are exploring other alternatives. Finding a liquid transportation fuel that (1) can be produced from domestic resources, (2) is carbon neutral, and (3) has minimal GHG impacts would allow the United States to reduce our dependence on foreign oil and decrease environmental burdens. In a recent State of Union address, the President stated his goal of displacing $20 \%$ of gasoline demand by renewable fuels and vehicle efficiency improvement - that translates to 35 billion gallons of biofuels and alternative fuels in 10 years.

Following dramatic growth in the ethanol industry, corn ethanol (EtOH) production reached a record 4.9 billion gallons in 2006 . Yet, this total accounts for only $2.3 \%$ of the total U.S. gasoline supply (in gallons of gasoline equivalent). Even considering a U.S. Department of Agriculture (USDA) projection that corn ethanol production could reach 12 billion gallons by 2017 (Collins 2007), a large gap remains to be filled by biofuels. Therefore, developments in feedstocks, processing technologies, and new biofuels are urgently needed if the United States is to meet the President's target of 35 billion gallons per year by 2017 .

Among potential biofuels, butanol $(\mathrm{BuOH})$ produced from starch has gained visibility in recent years as a replacement for gasoline. Butanol has unique properties as a fuel. The energy content of butanol — 99,840 Btu per gallon (low heating value [LHV]) - is $86 \%$ of the energy content of gasoline (on a volumetric basis) and 30\% higher than the energy content of ethanol. The low water solubility of butanol could minimize the co-solvency concern associated with ethanol, consequently decreasing the tendency of microbial-induced corrosion in fuel tanks and pipelines during transportation and storage. Butanol is much less evaporative than gasoline or ethanol, making it safer to use and generating fewer volatile organic compound (VOC) emissions. The majority of butanol used as a chemical is produced from petroleum propylene through the Oxo process (in which synthetic gas [syngas] is reacted with propylene), and its ultimate end use is for surface coatings.

The most dominant bio-butanol production process has been acetone-butanol-ethanol (ABE) fermentation. ABE fermentation by Clostridium acetobutylicum was the route used to produce butanol during World War II. It was phased out when more economical petrochemical routes emerged. Now, almost all butanol in the world is produced from petrochemical feedstocks. Research interest in developing viable $\mathrm{ABE}$ fermentation processes has been rekindled recently as a result of the pursuit of non-fossil-based feedstocks.

In the past 20 years, research and development (R\&D) efforts have focused on various aspects of the ABE process. Molecular biology research has achieved major breakthroughs in 
strain/mutant development that dramatically improved microbial tolerance to butanol toxicity, which resulted in a significant increase in ABE solvent production yield. Experimental and computational engineering efforts have included designing new schemes to minimize butanol inhibition by using new fermentor configurations, improved downstream processing, and process integration. Huang et al. (2004) reported an experimental process that uses continuous immobilized cultures of Clostridium tyrobutyricum and Clostridium acetobutylicum to maximize the production of hydrogen and butyric acid and convert butyric acid to butanol separately in two steps. This process reportedly produced butanol at a rate of 4.64 grams per liter of fermentation medium per hour $(\mathrm{g} / \mathrm{L} / \mathrm{h})$ and used $42 \%$ glucose, compared with the up-to- $25 \%$ glucose use rate in traditional $\mathrm{ABE}$ fermentation by Clostridium acetobutylicum alone.

In the early, 1990s Clostridium beijerinckii BA101 was developed by using chemical mutagenesis together with selective enrichment, which is able to produce twice as much butanol as its parent strain (US Patent 6358717). Extensive studies have been performed to characterize this strain and develop an ABE process with various feedstocks and evaluate technologies for downstream product separation (Qureshi and Blaschek 1999; Parek et al. 1999; Qureshi and Blaschek 2001a and 2001b). Experimental and pilot-scale ABE fermentation processes by this organism resulted in up to $95.1 \%$ glucose utilization in fermentation. Using in-situ gas stripping for solvent removal from fermentor minimizes product inhibition and enables higher feed concentration - up to $500 \mathrm{~g} / \mathrm{L}$ of glucose (Ezeji et al. 2004). Solvent production in this process in a fed-batch mode reached 65:35:1 of butanol:acetone:ethanol by weight, which is a significant increase in butanol production from 6:3:1 in conventional ABE process.

Liu (2003) presents an exhaustive survey of major research findings on ABE downstream processing. Recent studies have focused on integration of fermentation and product removal through in-situ gas stripping and fermentation gas recirculation (Qureshi and Blaschek 2000; Qureshi and Blaschek 2001a; Qureshi and Blaschek 2001b; Ezeji et al. 2004; and Ezeji et al. 2005). The latest development includes a DuPont patent (2007) describing a strain that produces butanol from biological feedstocks while minimizing acetone production. Cellulosic feedstock for butanol production has also been reported (Qureshi et al. 2007).

Researchers have employed computer simulations in developing butanol production processes, including ABE fermentation. The earliest efforts in downstream processing simulation of ABE fermentation were reported in Marlatt and Datta (1986) and Dadgar and Foutch (1988). In these studies, simulations were used to evaluate the economics of their processes. More recent studies were published in Liu (2003) and Liu et al. (2004 and 2006). In these studies, downstream processing systems were synthesized, simulated, and optimized in terms of cost. There are comparatively few publications on ABE fermentation process simulation. A corn-tobutanol pathway has been modeled by NRC (Natural Resources Canada, Feb. 2007) recently, on the basis of earlier work of conventional ABE fermentation. The study examined corn-based butanol used as $10 \%$ butanol in a gasoline blend to fuel light-duty vehicles. Simulation results for fuel ethanol produced from corn via dry milling, such as those obtained by using USDA's dry mill model (Kwiatkowski et al. 2006; McAloon 2006), are readily available.

Since 1995, with support primarily from DOE's Office of Energy Efficiency and Renewable Energy, Argonne has been developing the Greenhouse Gases, Regulated Emissions 
and Energy Use in Transportation (GREET) model. Argonne released the first version of the model - GREET 1.0 - in June 1996. GREET is a Microsoft ${ }^{\circledR}$ Excel $^{\mathrm{TM}}$-based multidimensional spreadsheet model that addresses the well-to-wheels (WTW) analytical challenges associated with transportation fuels (including ethanol) and vehicle technologies. The latest version GREET 1.7 - is capable of analyzing more than 100 transportation fuel pathways and 75 vehicle/fuel systems (Brinkman et al. 2005). The GREET model has been updated frequently to reflect new feedstocks, processing technologies, fuels, and vehicle systems. For a given vehicle and fuel system, GREET separately calculates:

- Consumption of total energy (energy in non-renewable and renewable sources), fossil fuels (petroleum, natural gas, and coal combined), petroleum, natural gas, and coal;

- Emissions of carbon-dioxide $\left(\mathrm{CO}_{2}\right)$-equivalent $\mathrm{GHGs}$ - primarily $\mathrm{CO}_{2}$, methane $\left(\mathrm{CH}_{4}\right)$, and nitrous oxide $\left(\mathrm{N}_{2} \mathrm{O}\right)$; and

- Emissions of six criteria pollutants: VOCs, carbon monoxide (CO), nitrogen oxides $\left(\mathrm{NO}_{\mathrm{X}}\right)$, particulate matter measuring 10 micrometers or less $\left(\mathrm{PM}_{10}\right)$, particulate matter measuring 2.5 micrometers or less $\left(\mathrm{PM}_{2.5}\right)$, and sulfur oxides $\left(\mathrm{SO}_{\mathrm{X}}\right)$.

These criteria pollutant emissions are further separated into total and urban emissions.

This study was an attempt to evaluate the potential of the recent ABE process from a lifecycle perspective. This estimate provides a life-cycle analysis (LCA) of the production and use of corn-derived bio-butanol as transportation fuel to displace petroleum gasoline. First, we developed an ABE process simulation model by using Aspen Plus ${ }^{\circledR}$. We used the energy and mass balance resulting from the Aspen Plus ${ }^{\circledR}$ simulation as a basis for a life-cycle analysis of corn-based butanol production and use. We estimated the life-cycle energy and GHG emissions impacts of corn-based butanol (produced via the ABE process) when used to displace gasoline as a transportation fuel in LDVs. We also performed a "cradle-to-user" analysis for bio-acetone (which is co-produced with bio-butanol) to address the impacts of displacing petroleum-based acetone with the bio-acetone co-product. Merits and shortfalls of such process are discussed in this report. 


\section{LCA SYSTEM BOUNDARY AND ANALYSIS SCENARIOS}

\subsection{SYSTEM BOUNDARY}

Figure 1 depicts the GREET modeling boundary for this study. The life cycle of biobutanol is divided into five stages:

1. Corn farming,

2. Corn transportation,

3. Bio-butanol production,

4. Bio-butanol transportation and distribution, and

5. Bio-butanol use in gasoline vehicles (GVs).

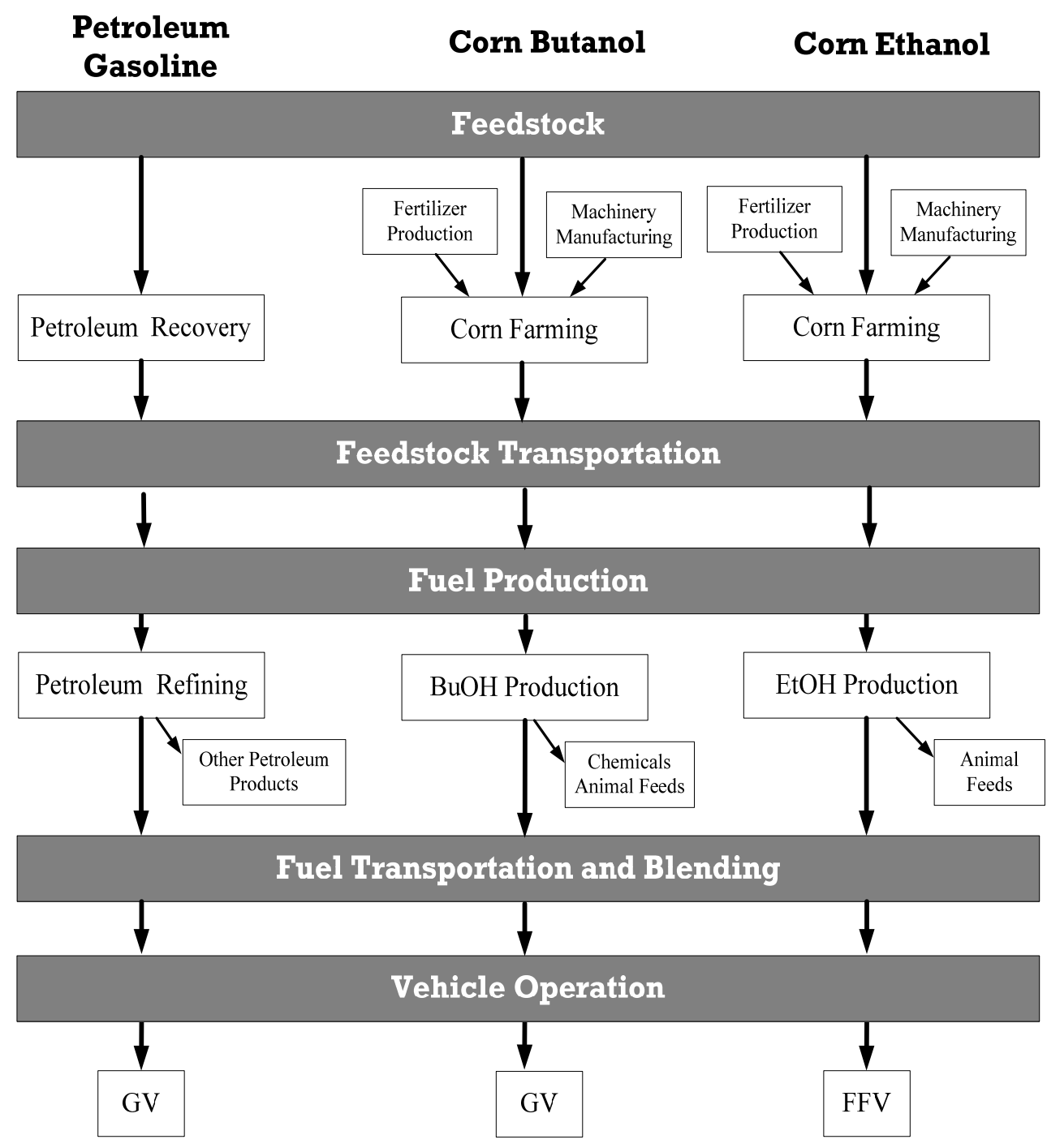

FIGURE 1 Schematic Representation of WTW Analysis System Boundaries for Butanol, Ethanol, and Gasoline 
The bio-butanol life cycle begins with the manufacture of fertilizer and farming machinery. Corn farming operations include irrigation, tillage, application of fertilizer, lime, herbicides, and pesticides, and corn harvest. Harvested corn grain is transported via barge, rail, and truck to fuel production facilities, where it undergoes biochemical (BC) processing for fuel production. The demand for heat and power (steam and electricity) from the BC processing is met by grid electricity and natural gas (NG). Liquid fuel is then transported to refueling stations via rail, barge, and truck. We assumed that bio-butanol would be used in unblended form in GVs. The gasoline life cycle, on the other hand, begins with crude oil recovery in oil fields and ends in gasoline combustion in GVs. The timeframe for the analysis is 2010 .

\subsection{ANALYSIS CASES}

This study analyzes a facility that produces 150,000 metric tons of bio-butanol per year, requiring 33 million bushels of corn equivalent to an 89-million-gallon-per-year (MMGY) corn ethanol dry mill. Corn-derived butanol (bio-butanol) is produced from fermentation that co-produces acetone, butanol, and ethanol (ABE), plus a small amount of fatty acids. The corn-derived butanol is assumed to displace gasoline in GVs on the basis of the similarities in the properties of the two fuels (Table 1).

Because current bio-butanol production technology is still in the early stages of research and development, we assumed a 2010 timeframe for a large-scale demonstration plant. During bio-butanol production, a large amount of acetone is generated as a co-product. Corn-based acetone could displace petroleum-based acetone. We established cases to compare biofuel butanol and biochemical acetone with their petroleum counterparts. For bio-butanol, we conducted a full life cycle (or WTW) analysis; for bio-acetone, we elected a "cradle-to-user" approach because of limited use data available in the open literature. The cradle-to-user analysis includes feedstock farming and transportation, bio-acetone production via $\mathrm{ABE}$ process, and acetone transport to user gate. Thus, we established a total of seven cases.

- Case 1: Conventional gasoline (baseline fuel).

- Case 2: Bio-butanol with natural gas as the process fuel, where bio-acetone is regarded as a chemical to displace petroleum-based acetone and is therefore credited by product displacement. Distiller's dried grains with solubles (DDGS) and ethanol displace animal feed and gasoline, respectively. 
- Case 3: Bio-butanol with natural gas as the process fuel, where acetone and DDGS are regarded as energy products and are thus credited on the basis of the energy allocation method among butanol, acetone, ethanol, and DDGS.

- Case 4: Bio-butanol with natural gas as the process fuel, where acetone is regarded as waste and therefore no acetone credit is assigned. DDGS and ethanol displace animal feed and gasoline, respectively.

- Case 5: Corn ethanol from dry milling with natural gas as the process fuel, where DDGS is credited by product displacement to displace animal feed (GREET default).

- Case 6: Corn ethanol from dry milling with natural gas as the process fuel, where DDGS is regarded as an energy product and is credited on the basis of the energy allocation method between ethanol and DDGS.

- Case 7: Cradle-to-user petroleum-acetone (baseline chemical) analysis for examining displacement of petroleum acetone by bio-acetone. Butanol, DDGS, and ethanol are credited by product displacement.

We established a bio-butanol life-cycle framework on the basis of Aspen Plus ${ }^{\circledR}$ process simulation and existing GREET, as shown in Figure 1. We adopted feedstock corn farming and transportation values from GREET's corn ethanol pathway. Bio-butanol is produced, together with acetone and ethanol, from a corn dry mill by retrofitting the mill to accommodate the ABE fermentation and separation process. The bio-butanol production process is simulated by using the Aspen Plus ${ }^{\circledR}$ model. We approximated the other process steps (grain feed handling, cooking, and DDGS drying) on the basis of a corn dry mill cost model from USDA (Kwiatkowski et al. 2006; McAloon 2006) and results from a recent study (Mueller and Cuttia 2006). Data from these sources and Aspen Plus ${ }^{\circledR}$ simulations were then integrated and scaled to obtain the entire bio-butanol plant mass and energy flow. Data from the mass and energy balance of the biobutanol plant serve as input parameters to the GREET model for the WTW analysis.

We estimated the energy consumption (of both petroleum oil and fossil energy) and the emissions of GHGs $\left(\mathrm{CO}_{2}, \mathrm{~N}_{2} \mathrm{O}\right.$, and $\left.\mathrm{CH}_{4}\right)$ that occurred over the entire fuel cycle. Energy and emissions were partitioned to all products resulting from the process according to either the displacement or the energy allocation method (see Section 4.3). Finally, we determined fuel transportation and vehicle operation parameters to complete the bio-butanol fuel life cycle. We then compared scenarios for bio-butanol and ethanol produced from conventional corn dry mills to gasoline. Section 4.4 addresses the cradle-to-user analysis of bio-acetone. 


\section{ASPEN PLUS ${ }^{\circledR}$ SIMULATION OF THE ABE PROCESS}

The simulation of ABE fermentation and downstream processing was completed by using Aspen Plus ${ }^{\circledR}$ and Microsoft Excel ${ }^{\circledR}$. Section 3.1 presents the basis of this simulation, including scope, plant capacity, and product specifications. Section 3.2 presents an overview of the simulated process; upstream raw material processing is also included to provide the context for the simulated process. Mass and energy balances derived from the ABE fermentation and downstream processing simulation are presented at the end of Section 3.3. The results are further integrated into the whole plant to include corn grain pretreatment, saccharification, and DDGS drying. Section 4.1 presents the energy balance of the bio-butanol plant.

\subsection{SCOPE AND METHOD}

The bio-butanol plant produces butanol from corn via ABE fermentation. Our Aspen Plus ${ }^{\circledR}$ simulation is based on two data sources. For the portion of the process upstream from ABE fermentation (i.e., grain pre-treatment, liquefaction, and saccharification), we adopt the results from a USDA Aspen Plus ${ }^{\circledR}$ simulation model for a corn dry mill (Kwiatkowski et al. 2006; McAloon 2006), because the upstream results of fermentation would be similar to those of a corn dry mill and can therefore be modeled the same way. For a similar reason, co-product DDGS drying is simulated after the USDA model.

For the second half of the process, including ABE fermentation and downstream processing, the ASPEN simulation was completed on the basis of the research results from a pilot-scale ABE fermentation plant (Ezeji et al. 2003 and 2004) and from literature (Liu 2003; Liu et al. 2004, 2006; Heckl et al. 2006). The production capacity of this plant was set at 150,000 metric tons per year of butanol. The operation runs 315 days per year. Product and byproduct specifications were as follows: butanol purity, $99.5 \%$ by weight (wt $\%$ ); acetone purity, $99.5 \mathrm{wt} \%$; and ethanol purity, $99.5 \mathrm{wt} \%$.

\subsection{OVERVIEW OF ABE PROCESS}

The ABE fermentation simulation describes a process developed by Qureshi and Blaschek (1999; 2001a, b). Acetone, butanol, and ethanol (ABE) are produced by a hyperbutanol-producing strain (C. beijerinckii BA101). Corn is fed into a conventional corn dry mill for conversion to glucose through liquefaction and saccharification. The glucose is fermented to $\mathrm{ABE}$ through a fed-batch system. After fermentation, the ABE compounds are removed by means of in-situ gas stripping. ABE products are recovered through molecular sieve adsorption and a three-stage distillation that separates the acetone, butanol, and ethanol. Solids and biomass that are removed from grain processing and fermentation undergo centrifugation and proceed to drying, along with syrup from distillation; DDGS generated from drying is used as animal feed. The following subsections provide brief descriptions of the process for producing butanol from corn. The process consists of three main parts: grain pre-treatment (receiving, liquefaction, and saccharification), fermentation and gas stripping, and downstream processing. 


\subsubsection{Grain Receiving, Liquefaction, and Saccharification}

This section describes of the portion of the conventional dry grind ethanol process that begins with receipt of grain and ends with saccharification, as modeled in the USDA Aspen Plus ${ }^{\circledR}$ simulation of the corn ethanol process (Figure 2). We use the data derived from this part of the corn ethanol process in the USDA's 40-mmgy dry mill model to simulate the ABE fermentation process, except we scaled the capacity from 40 MMGY of ethanol to 150,000 metric tons of butanol per year.

Corn brought into the plant site is first separated from finer particles and foreign objects by using a blower and screens. The cleaned, dry corn is ground in a hammer-mill and weighed to control the feed rate to the process. In the liquefaction step, the ground corn is then mixed with water, thermo-stable alpha-amylase, ammonia, and lime in a slurry tank.

A steam injection heater is used to gelatinize the starch, which is then hydrolyzed by the alpha-amylase into oligosaccharides. The stream is then "cooked" and transferred to the saccharification tank, where the oligosaccharides are converted by glucoamylase to glucose at a temperature of $61^{\circ} \mathrm{C}$. The slurry is then transferred to an evaporator to concentrate the feed to the desired level for $\mathrm{ABE}$ fermentation.

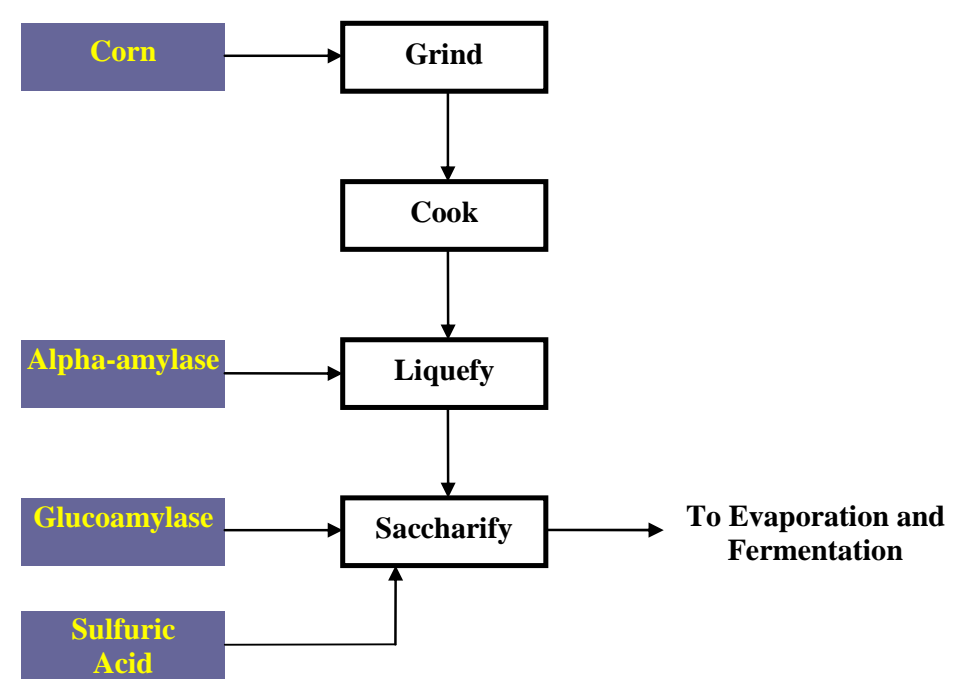

FIGURE 2 Schematic for Grain Receiving, Liquefaction, and Saccharification 


\subsubsection{Fermentation and In-Situ Gas Stripping}

The information in this section is based on the research results from Qureshi and Blaschek (2000; 2001a, b), Ezeji et al. (2004), and Ezeji et al. (2005).

The literature reported that the strain C. beijerinckii BA101 can produce butanol in a range of sugar concentrations from 45.4 to $500 \mathrm{~g} / \mathrm{L}$. Because typical sugar concentration in fermentation feed is $3-7 \%$ (White and Johnson 2003) in a corn ethanol plant, it is desirable to concentrate this stream, which provides a means to integrate the grain processing in corn dry milling with the ABE process we modeled. Further, it could potentially reduce energy demand associated with removing water from ABE products in downstream processing. (Operational issues with respect to the concentrated feed will be discussed later in this section.) The stream that departs from saccharification goes to an evaporator to concentrate the sugar to $430 \mathrm{~g} / \mathrm{L}$ before entering $\mathrm{ABE}$ fermentation. Alternative technologies to provide concentrated feed are available and could be used. Nevertheless, this step represents a large amount of heat demand and a capital cost. Our Aspen Plus ${ }^{\circledR}$ simulation begins at this step. The slurry feed generated from evaporation is then cooled to $35^{\circ} \mathrm{C}$ and introduced to the oxygen-free fermentation vessel, which has been inoculated with C. beijerinckii BA101. The temperature is controlled at $35^{\circ} \mathrm{C}$, and no $\mathrm{pH}$ adjustment is applied during the process.

ABE fermentation is operated in a fed-batch mode. ABE production typically starts with a lag phase and gradually increases its rate until the $\mathrm{ABE}$ concentration reaches a plateau before it finally decreases (Ezeji et al. 2004). A gas mixture of carbon dioxide $\left(\mathrm{CO}_{2}\right)$ and hydrogen $\left(\mathrm{H}_{2}\right)$ is also generated from the fermentation. This gaseous mixture is recirculated via a gas pump to maintain a head pressure that ensures the anaerobic environment necessary for the microorganism. ABE products are removed by in-situ stripping from the fermentor by using the gaseous mixture from fermentation. At start-up, the fermentation proceeds for $22 \mathrm{~h}$, until ABE reaches about $5 \mathrm{~g} / \mathrm{L}$, and then gas stripping is applied. The $\mathrm{ABE}$ vapors that are stripped from the fermentor enter a condenser above the fermentor, and the $\mathrm{ABE}$ vapors are cooled to $10^{\circ} \mathrm{C}$ and condensed to liquids, leaving uncondensed $\mathrm{CO}_{2}$ and $\mathrm{H}_{2}$ in the vapor phase to be recirculated. Excessive $\mathrm{CO}_{2}$ and $\mathrm{H}_{2}$ are vented to the atmosphere after passing through a $\mathrm{CO}_{2}$ scrubber. The gas stripping captures most of the butanol, acetone, and ethanol produced during fermentation. The selectivity of the stripping for butanol, defined as

$$
[\mathrm{y} /(1-\mathrm{y})] /[\mathrm{x} /(1-\mathrm{x})],
$$

where: $\mathrm{x}=\mathrm{wt} \%$ of butanol in fermentation broth and

$\mathrm{y}=\mathrm{wt} \%$ of butanol in condensate,

is set at 20 (Qureshi and Blaschek 2001b). Accordingly, about $25 \mathrm{wt} \%$ water is present in the condensate; the water will be removed from the product and by-products in the downstream processing stage.

Microbial reaction mechanisms for the conversion of glucose to ABE have not been fully understood and characterized. In principle, the following biochemical reactions could describe the ABE fermentation: 


$$
\begin{aligned}
& \mathrm{C}_{6} \mathrm{H}_{12} \mathrm{O}_{6} \rightarrow \mathrm{C}_{4} \mathrm{H}_{10} \mathrm{O} \text { (butanol) }+\mathrm{CO}_{2}+\mathrm{H}_{2} \mathrm{O} \\
& \mathrm{C}_{6} \mathrm{H}_{12} \mathrm{O}_{6}+\mathrm{H}_{2} \mathrm{O} \rightarrow \mathrm{C}_{3} \mathrm{H}_{6} \mathrm{O} \text { (acetone) }+\mathrm{CO}_{2}+\mathrm{H}_{2} \\
& \mathrm{C}_{6} \mathrm{H}_{12} \mathrm{O}_{6} \rightarrow \mathrm{C}_{2} \mathrm{H}_{5} \mathrm{O} \text { (ethanol) }+\mathrm{CO}_{2}+\mathrm{H}_{2} \\
& \mathrm{C}_{6} \mathrm{H}_{12} \mathrm{O}_{6} \rightarrow \mathrm{C}_{4} \mathrm{H}_{8} \mathrm{O}_{2} \text { (butyric acid) }+\mathrm{CO}_{2}+2 \mathrm{H}_{2} \\
& \mathrm{C}_{6} \mathrm{H}_{12} \mathrm{O}_{6} \rightarrow \mathrm{C}_{2} \mathrm{H}_{4} \mathrm{O}_{2} \text { (acetic acid) }
\end{aligned}
$$

The reactions represent a qualitative measure rather than stoichiometric quantitative relationships for the ABE conversion process. The microbial cell growth was not included in any of the reactions above. In our simulation, the extent of $\mathrm{ABE}$ conversion is set according to literature value reported from experimental tests. Glucose utilization is $95.1 \%$ (i.e., $4.9 \%$ glucose is converted into biomass solids as a result of microbial growth). Butanol, acetone, ethanol, acetic acid, and butyric acid yields are 0.303, 0.155, 0.0068, 0.0086, $0.0084 \mathrm{~g} / \mathrm{g}$ glucose, respectively (Table 2).

As we noted earlier in this section, integrating the conventional corn ethanol dry mill process with the new ABE process requires closing a gap in the concentration of the sugar feed to the fermentor between the two processes. Feed for the ABE fermentation process contains a sugar concentration of up to eight-fold as high as that of conventional corn ethanol process, which suggests a small footprint for a fermentation and downstream processing unit and, therefore, lower capital expenditure and lower energy demand for downstream separation. However, at such a concentration, the solids could build up to $55 \%$ (wt/wt) or higher in the fermentor. In comparison, the level of solids in corn ethanol fermentation is roughly $20 \%$ (wt/wt). The level of solids in ABE fermentation broth means increased viscosity, which could result in inhibitory stress on microorganisms and operational difficulties. In addition, feed to a fermentor in a corn dry mill usually contains corn fiber, which could exhibit mass-transfer limitation during gas stripping. The net result could be increased energy consumption for gas stripping or reduced product removal efficiency by stripping. Data in the literature are mostly based upon relatively pure glucose/nutrient feed in which mass transfer may not be limiting. The operability and mass-transfer issues in fermentation for the corn-to-butanol process should therefore be examined carefully. For comparison, we estimated a case with diluted feed to the fermentor (no evaporation), which is similar to the fermentation feed in an existing corn ethanol plant.

Another uncertainty is that $\mathrm{ABE}$ fermentation requires a pure form of starch that is similar to starches produced from a wet milling process. Additional steps to purify dry milling starch will be necessary to integrate the dry mill with the ABE fermentation. Unfortunately, at the time of this study, available data were limited to pilot-scale testing, and the corn-to-butanol ABE process is not well established. We did not including starch purification step. Our analysis will be updated once these issues have been addressed and data become publicly available.

\subsubsection{Downstream Processing}

The liquid fermentation broth from the condenser is subject to a series of distillation operations in which the stream is separated into product, based on their volatilities: $99.5 \mathrm{wt} \%$ pure butanol, $99.5 \mathrm{wt} \%$ pure acetone, and $99.5 \mathrm{wt} \%$ pure ethanol. In a mixture containing 
butanol, ethanol, and water, homogeneous ethanol-water azeotrope and heterogeneous waterbutanol azeotrope are formed. In descending order of their volatilities, the components in the stream (including the two azeotropes) to be separated by the downstream processing are acetone, azeotrope of ethanol and water, ethanol, azeotrope of water and butanol, water, and butanol. The components in this sequence could plausibly be separated simply by fractional distillation, achieved by various simple and/or complex column configurations, into any two or more subsequences of components at the adjacent components that have sufficiently different volatilities.

The fermentation broth is first fed to the first distillation tower, where a composition cut is made to separate acetone, ethanol, and water from the broth. These components are sent to the top stream, and the butanol (together with a trace amount of water) goes to the bottom stream. The product butanol is $99.5 \mathrm{wt} \%$ pure and suitable for transportation fuel use. The top stream is sent to a second distillation tower, where acetone is concentrated, purified, and then sent out from the top. The bottom stream, containing mainly ethanol and water, is subject to further separation in a third distillation tower, where the azeotropic vapor of $94.4 \mathrm{wt} \%$ ethanol and $5.3 \mathrm{wt} \%$ water (and $2 \mathrm{wt} \%$ acetone) is withdrawn from the top and sent to an adsorption unit. The water stream from the bottom is sent back to the fermentor. Water in the top stream is adsorbed in this unit, and ethanol purity in the product stream reaches $99.5 \%$ (the minimum purity required for ethanol to be blended with gasoline and used in vehicles).

The adsorption unit consists of two adsorption columns that run cyclically between the adsorption and desorption phases. Molecular sieves are packed in the column as the adsorbents. The sieves consist of a microporous substance designed to separate small polar molecules from larger nonpolar ones via a sieving action. Water molecules are trapped and adsorbed inside the microporous beads, while the ethanol molecules flow around them. Molecular sieves are then regenerated by heat and carrier air. Figure 3 presents the schematic of the adsorption and adsorbent regeneration process.

\subsection{PROCESS FLOWSHEET SIMULATED BY ASPEN PLUS ${ }^{\circledR}$}

\subsubsection{ABE Process Flowsheet}

This simulation attempts to address the potential of the new ABE fermentation with an in-situ stripping process, by using the best of the process value reported. The ABE fermentation and downstream processing (separation) model from this study was integrated with the upstream grain processing component of the USDA's corn dry mill model and scaled to the 150,000-metric-ton-per-year bio-butanol production level. Figure 4 shows the Aspen Plus ${ }^{\circledR}$ output of the process flowsheet from fermentation to downstream processing. Data for the simulation of fermentation and gas-stripping unit operations are based on the research results from Qureshi and Blaschek (2000; 2001a,b), Ezeji et al. (2004), and Ezeji et al. (2005). Table 2

summarizes the main parameters for fermentation and gas stripping input to the Aspen Plus ${ }^{\circledR}$ simulation. 


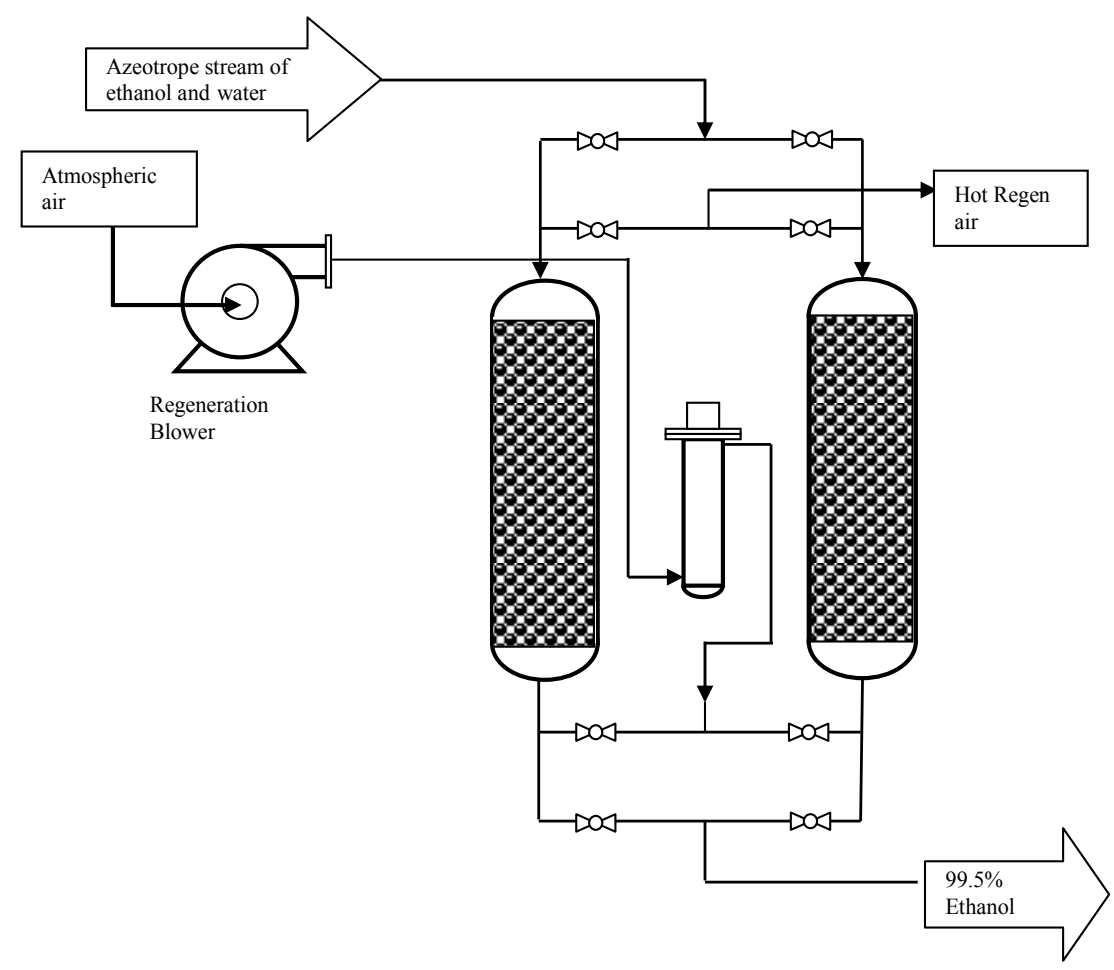

FIGURE 3 Schematic Representation of Adsorption and Adsorbent Regeneration

The downstream processing flowsheet in the simulation is based on the most costeffective flowsheet rigorously generated from an exhaustive list of plausible processing equipment and unit operations, as described in Liu (2003), Liu et al. (2004, 2006), and Heckl et al. (2006). According to their studies, this optimal flowsheet consists of a gas stripper that isolates a liquid product stream from the fermentation broth; an adsorption unit that removes the majority of water; and a set of distillation columns that purifies the butanol, ethanol, and acetone products. The studies show that the cost of this flowsheet is at least $12.5 \%$ lower than that of any other alternative flowsheet. Energy use for the regeneration of the molecular sieve adsorbents is calculated off-line. The calculation, presented in Section 3.3.2, is then incorporated into the simulation by using a Fortran subroutine.

Shortcut methods that highlight the mass and energy balances are chosen for simulating most of the unit operations in the process. Heat integration between the three distillation columns is taken into consideration. Our simulation did not include stream recycling and simple unit operations (such as valves); we also did not examine different distillation column configurations.

The combined Aspen Plus ${ }^{\circledR}$ model provides the material balance for the bio-butanol plant, as shown in Table 3. Table 4 lists the yields of acetone, butanol, and ethanol from the biobutanol plant (in gallon per bushel [gal/bu] of corn). Steam and electricity use for the ABE process (Table 5) indicates that using concentrated feed for ABE fermentation could save $14 \%$ of steam needs, in comparison with using existing feed in a dry mill. Among the reductions in steam needs, $75 \%$ of those reductions come from distillation. Section 4.1 presents the energy balance for the bio-butanol plant from gate to gate. 


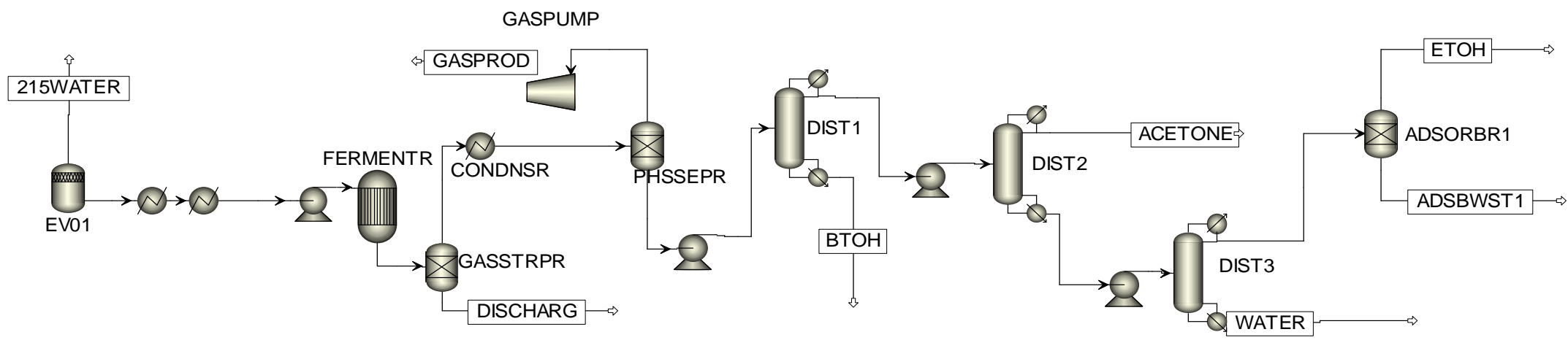

FIGURE 4 Aspen Plus ${ }^{\circledR}$ Output of the Process Flowsheet from Fermentation to Downstream Processing 
TABLE 2 Main Input Parameters for Fermentation and Gas Stripping for Aspen Plus ${ }^{\circledR}$ Simulations

\begin{tabular}{|c|c|c|}
\hline \multicolumn{2}{|c|}{ Input Parameter } & $\begin{array}{l}\text { Value Used in } \\
\text { the Simulation }^{\text {a }}\end{array}$ \\
\hline \multicolumn{2}{|c|}{ Fermentor operating temperature $\left({ }^{\circ} \mathrm{C}\right)$} & 35 \\
\hline \multicolumn{2}{|c|}{ Fermentor operating pressure (atm) } & 1 \\
\hline \multirow{8}{*}{$\begin{array}{l}\text { Yield (gram/ } \\
\text { gram glucose) }\end{array}$} & Acetone & 0.155 \\
\hline & Butanol & 0.303 \\
\hline & Ethanol & 0.0068 \\
\hline & $\mathrm{ABE}$ (total) & 0.465 \\
\hline & Acetic acid & 0.0086 \\
\hline & Butyric acid & 0.0084 \\
\hline & Hydrogen & 0.021 \\
\hline & Carbon dioxide & 0.6954 \\
\hline \multicolumn{2}{|c|}{ Gas stripping carrier gas } & Fermentation gas \\
\hline \multicolumn{2}{|c|}{ Gas stripping selectivity for butanol } & 20.0 \\
\hline \multicolumn{2}{|c|}{ Condensation temperature $\left({ }^{\circ} \mathrm{C}\right)$} & 2 \\
\hline
\end{tabular}

a Sources: Ezeji et al. (2004); Qureshi et al. (2001b)

TABLE 3 Material Balance of Bio-Butanol Plant

\begin{tabular}{lrl}
\hline \multicolumn{1}{c}{ Parameter } & Value & \multicolumn{1}{c}{ Source } \\
\hline Feed grain moisture content $(\%)$ & 15 & $\begin{array}{l}\text { USDA dry mill model (Kwiatkowski et al. 2006; } \\
\text { McAloon 2006) }\end{array}$ \\
Corn grain feed rate (lb corn/h) & 237,338 & $\begin{array}{l}\text { Aspen Plus }{ }^{\circledR} \text { results scaled up from USDA dry } \\
\text { mill model (Kwiatkowski et al. 2006; McAloon }\end{array}$ \\
2006) & & \\
Glucose feed rate to fermentor & 154,871 & Aspen Plus ${ }^{\circledR}$ simulation (this study) \\
(lb/h) & & \\
Production $(\mathrm{lb} / \mathrm{h})$ & 23,997 & \\
Acetone & 42,728 & \\
Butanol & 1,032 & \\
Ethanol & 73,816 & \\
DDGS & 11 & \\
DDGS moisture content $(\%)$ &
\end{tabular}


TABLE 4 Yields of Acetone, Butanol, and Ethanol from Bio-Butanol Plant

\begin{tabular}{lccc}
\hline Product & $\begin{array}{c}\text { Yield } \\
\text { (gal/bu corn) }\end{array}$ & $\begin{array}{c}\text { Energy } \\
(\text { Btu/bu corn })\end{array}$ & $\begin{array}{c}\text { Energy Output Share } \\
(\%)\end{array}$ \\
\hline & & & \\
Acetone & 0.868 & 69,525 & 31.4 \\
Butanol & 1.495 & 149,267 & 67.4 \\
Ethanol & 0.037 & 2,828 & 1.2 \\
Total & 2.4 & 221,621 & 100 \\
\hline
\end{tabular}

TABLE 5 Process Fuel Use for ABE Fermentation and Downstream Processing

\begin{tabular}{lrrc}
\hline \multicolumn{1}{c}{ Process Step } & Steam $(\mathrm{Btu} / \mathrm{h})$ & Electricity $(\mathrm{kW})$ & $\begin{array}{c}\text { Diluted Sugar Feed to Fermentor } \\
\mathrm{a}^{\mathrm{a}}\end{array}$ \\
\hline Evaporator & $278,653,091$ & & Steam $(\mathrm{Btu} / \mathrm{h})$ \\
Fermentor agitator & & 192.73 & 0 \\
Condenser & & 3105.40 & \\
Gas pump & 61.04 & $1,412,700$ \\
Gas stripper & $1,307,400$ & & \\
Adsorption feed pump & & 0.24 & $68,173,300$ \\
Distillation Column 1 & $43,220,100$ & & $10,891,300$ \\
Distillation Column 2 & $62,665,700$ & & \\
Distillation Column 3 & $5,730,860$ & & \\
Distillation 2 feed pump & & 0.40 & $-729,205$ \\
Distillation 3 feed pump & & 0.03 & \\
Adsorbent regeneration & $-729,205$ & 237.33 & \\
\hline
\end{tabular}

${ }^{\text {a }}$ Existing fermentation feed, such as those from corn dry mill used for ABE fermentation.

\subsubsection{Estimate of Energy Use for Adsorbent Regeneration}

The heat use for the regeneration of adsorbents is calculated as the total amount required to bring the system — which includes the adsorption column, the molecular sieves, adsorbed water, and the carrier gas - to a temperature of $500^{\circ} \mathrm{F}$. An electric heater provides the energy requirement for absorbent regeneration. The system is cooled by exchanging the heat with the process streams fed to the distillation towers (assuming a loss factor of $10 \%$ ). Therefore, the energy used to cool the system is not taken into account. The weight of water that the molecular sieves adsorb is set at $22 \%$ of the weight of the molecular sieve. The peak concentration of water in the carrier air is set at $1.7 \mathrm{wt} \%$. The adsorption and regeneration cycle time is set at $8 \mathrm{~h}$. The amount of heat required to bring the column to the specified temperature is calculated by using a method based on logarithmic mean temperature difference (LMTD) and the scaling of experimental data. The radiation loss factor for heater is set at 5\%. Other major parameters for the calculation are listed in Table 6. 
TABLE 6 Parameters for Calculating Energy Use for Adsorbent Regeneration

\begin{tabular}{|c|c|c|c|c|}
\hline Parameter & $\begin{array}{c}\text { Water Adsorbed } \\
\text { Inside Molecular } \\
\text { Sieves } \\
\end{array}$ & Molecular Sieves & $\begin{array}{l}\text { Adsorption } \\
\text { Column }\end{array}$ & $\begin{array}{c}\text { Carrier Gas - } \\
\text { Air }\end{array}$ \\
\hline Amount (lb/h) & 55.6 & $2,020.0$ & $\mathrm{n} / \mathrm{a}$ & $3,333.0$ \\
\hline $\mathrm{Cp}\left(\mathrm{btu} / \mathrm{lb} /{ }^{\circ} \mathrm{F}\right)$ & 1.0 & 0.2 & $\mathrm{n} / \mathrm{a}$ & 0.2 \\
\hline $\mathrm{T} 1\left({ }^{\circ} \mathrm{F}\right)$ & 175.0 & 175.0 & 175.0 & 175.0 \\
\hline $\mathrm{T} 2\left({ }^{\circ} \mathrm{F}\right)$ & 500.0 & 500.0 & 500.0 & 500.0 \\
\hline$\Delta \mathrm{T}\left({ }^{\circ} \mathrm{F}\right)$ & 325.0 & 325.0 & 325.0 & 325.0 \\
\hline $\mathrm{Q}(\mathrm{Btu} / \mathrm{h})$ & $18,053.8$ & $150,995.0$ & $343,706.1$ & $258,890.8$ \\
\hline Total (Btu/h) & $810,227.9$ & & & \\
\hline
\end{tabular}




\section{BIO-BUTANOL LIFE-CYCLE ASSESSMENT}

\subsection{BIO-BUTANOL PLANT ENERGY REQUIREMENTS}

We assume that the bio-butanol plant uses natural gas as process fuel to generate steam and purchases electricity from the grid. Our process fuel estimate for the butanol plant is based on three sources: (1) the Aspen Plus ${ }^{\circledR}$ simulation of $\mathrm{ABE}$ fermentation and downstream processing from this study, (2) a recent study by Mueller and Cuttica (2006) of process fuel use in corn ethanol dry mills, and (3) the USDA corn dry mill model (Kwiatkowski et al. 2006; McAloon 2006). Aspen Plus ${ }^{\circledR}$ results from this simulation generate process fuel use values for ABE fermentation and downstream processing (Table 5). Considering the similarity in upstream grain processing between corn ethanol and corn butanol process in this study, we adopted the grain processing and DDGS drying steps from USDA dry mill model, scaling-up the corn feed for the bio-butanol plant. Thus, the heat and power needs in the rest of the plant (for cooking, the regenerative thermal oxidizer [RTO], and DDGS drying) are based on sources (2) and (3).

An estimate of process fuel (natural gas) use for cooking, DDGS drying, and RTO in the corn butanol plant was based on the amount of corn feed processed in the following steps. We first converted the energy input per gallon of ethanol to energy input per bushel of corn feed at a yield of 2.72 gallons of denatured ethanol per bushel of corn. We then converted this value to energy use per gallon of bio-butanol, with a bio-butanol yield of 1.50 gallons per bushel of corn (Table 4) for each process step above. In a conventional corn ethanol dry mill, water is removed from WDG (solids from grain processing) and syrup (solids from distillation) at the drying step and from ethanol via distillation. The ABE fermentation process described in this study partially removes water before fermentation to concentrate feed sugar content. Therefore, it is likely that less water will be removed at downstream processing and DDGS drying, which means lower energy demand. Another parameter that has not been fully evaluated and reported is DDGS yield from the corn-to-butanol ABE process and its quality. We assume equivalent heating demands for DDGS drying in the ethanol plant and in the butanol plant. Table 7 details the calculations of natural gas use in the bio-butanol plant. This steam demand is met by using a natural-gas-fired steam boiler with $80 \%$ efficiency to produce 150 -psi, medium-pressure steam.

Electricity demand for the bio-butanol plant was estimated in a similar way. According to the ethanol plant study by Mueller and Cuttica (2006), the average electricity use in corn ethanol plants is $0.75 \mathrm{kWh}$ per gallon of ethanol, which agrees with the value estimated by an ethanol plant designer (Roddy 2006), while it is slightly higher than the $0.73 \mathrm{kWh}$ per gallon of ethanol suggested by the USDA model. We used the former estimate in this analysis to reflect the current industry average. Electricity used for fermentation and distillation in the corn ethanol plant was displaced by that for $\mathrm{ABE}$ fermentation and downstream processing. The power consumption value was converted from per gallon of ethanol to per gallon of butanol via per bushel of corn on the basis of 2.72 gallons of $\mathrm{EtOH} / \mathrm{bushel}$ and 1.50 gallons of bio-butanol/bushel. Table 8 summarizes the major assumptions and data sources for power use in the bio-butanol plant. 
TABLE 7 Thermal Energy Requirements in Bio-Butanol Plant

\begin{tabular}{lccc}
\hline \multicolumn{1}{c}{ Process Steps } & $\begin{array}{c}\text { EtOH Plant NG } \\
\text { Required (Btu/gal } \\
\text { denatured EtOH) }\end{array}$ & $\begin{array}{c}\text { BtOH Plant NG } \\
\text { Required Based on } \\
\text { Feed Corn } \\
(\text { Btu/bu corn })^{\mathrm{c}}\end{array}$ & $\begin{array}{c}\text { BtOH Plant NG } \\
\text { Required Based on } \\
\text { BtOH } \\
(\mathrm{Btu} / \mathrm{gal} \mathrm{BtOH})^{\mathrm{d}}\end{array}$ \\
\hline $\begin{array}{l}\text { Cooking } \\
\begin{array}{l}\text { Dryer and RTO } \\
\text { ABE fermentation }\end{array}\end{array}$ & $10,013^{\mathrm{a}, \mathrm{b}}$ & 27,236 & 18,216 \\
and processing & 10,830 & 29,458 & 19,703 \\
BtOH plant total & & & 77,195 \\
\hline
\end{tabular}

a Source: Mueller (2006). 23.1\% total process fuel for cooking; 26.5\% for EtOH processing. Therefore, cooking fuel use is $23.1 \% /(23.1 \%+26.5 \%)=46.57 \%$ of total fuel used in ethanol processing (excluding DDGS drying).

${ }^{\mathrm{b}}$ The total thermal fuel requirement for cooking, fermentation, and distillation is 21,500 Btu/gal denatured EtOH in a 100-MMGY ethanol dry mill. Source: Mueller and Cuttica (2006). NG needed for cooking is $46.57 \% \times 21,500 \mathrm{Btu} / \mathrm{gal}=10,013 \mathrm{Btu} / \mathrm{gal} \mathrm{EtOH}$.

${ }^{c}$ Assumed corn ethanol yield: $2.72 \mathrm{gal} / \mathrm{bu}$ (denatured).

${ }^{\mathrm{d}}$ Corn butanol yield: $1.50 \mathrm{gal} / \mathrm{bu}$ of corn.

e Source: Mueller and Cuttica (2006).

${ }^{\mathrm{f}}$ Aspen Plus ${ }^{\circledR}$ results from this study includes heat for evaporation, fermentation, distillation, and gas stripping.

TABLE 8 Electricity Consumption in Bio-Butanol Plants

\begin{tabular}{lccc}
\hline \multicolumn{1}{c}{ Item } & $\begin{array}{c}\text { EtOH Plant } \\
\text { Electricity Required } \\
(\mathrm{kWh} / \mathrm{gal} \mathrm{EtOH})\end{array}$ & $\begin{array}{c}\text { BtOH Plant } \\
\text { Electricity Required } \\
\text { Based on Feed Corn } \\
(\mathrm{kWh} / \mathrm{bu})\end{array}$ & $\begin{array}{c}\text { BtOH Plant } \\
\text { Electricity Required } \\
\text { Based on BtOH } \\
\left(\mathrm{kWh} / \mathrm{gal} \mathrm{BtOH}^{\mathrm{a}}\right)\end{array}$ \\
\hline $\begin{array}{l}\text { EtOH plant } \\
\text { btOH plant, excluding }\end{array}$ & 0.75 & 2.04 & \\
$\begin{array}{l}\text { EtOHentation and distillation } \\
\text { fermen }\end{array}$ & $0.68^{\mathrm{c}}$ & 1.84 & 1.23 \\
$\begin{array}{l}\text { ABE fermentation and } \\
\text { separation }\end{array}$ & & & $0.53^{\mathrm{d}}$ \\
BtOH plant total & & & 1.76 \\
\hline
\end{tabular}

a Converted from $\mathrm{kWh} / \mathrm{bu}$ to $\mathrm{kWh} / \mathrm{gal} \mathrm{BtOH}$, with a corn butanol yield of $1.50 \mathrm{gal} / \mathrm{bu}$.

b Source: Mueller and Cuttica (2006). Converted to per bushel with an assumed corn ethanol yield of 2.72 gal denatured ethanol/bu.

${ }^{c}$ Calculated on the basis of USDA dry mill model: fermentation requirement $0.06 \mathrm{kWh} / \mathrm{gal}$ EtOH and $0.01 \mathrm{kWh} / \mathrm{gal}$ for distillation are subtracted from $0.75 \mathrm{kWh} / \mathrm{gal} \mathrm{EtOH}$.

${ }^{\mathrm{d}}$ Electricity needs from ABE fermentation and separation. Aspen Plus ${ }^{\circledR}$ results from this study. 
Scale-up from pilot test to full-scale commercial production could change the yield and energy consumption. These factors affect the overall bio-butanol production and energy use estimates.

\subsection{BUTANOL LIFE-CYCLE PARAMETERS}

Bio-butanol in this study is produced from corn. It would be economical for the biobutanol plant to be built near corn farms to reduce transportation costs. Operations associated with corn farming and feedstock transportation would be similar to those for corn. Bio-butanol produced from corn will displace gasoline; therefore, transportation, storage, and distribution of bio-butanol would be similar to those of ethanol. Table 9 presents key assumptions and GREET inputs for the bio-butanol life-cycle analysis. Electricity for the bio-butanol plant is supplied from the U.S. electric generation mix (Table 10).

TABLE 9 GREET Input Parameters for Corn Butanol WTW Analysis: Corn Farming, Transportation of Corn and Butanol, and Vehicle Operation

\begin{tabular}{lc}
\hline \multicolumn{1}{c}{ Parameters } & Assumptions \\
\hline $\begin{array}{l}\text { Corn yield (bu/harvested acre) } \\
\text { Ratio of harvested acreage to planted } \\
\text { acreage }\end{array}$ & 158 \\
Fertilizer use (g/bu) & $\mathrm{N}=420, \mathrm{P}_{2} \mathrm{O}_{5}=149$, \\
& $\mathrm{K}_{2} \mathrm{O}=174^{\mathrm{a}}$ \\
$\mathrm{CO}_{2}$ emissions from potential land use & 195 \\
changes of farming (g/bu) & 1,202 \\
Lime use (g/bu) & \\
Corn transportation mode and distance (mi) & 50 \\
Truck (100\%) & \\
Butanol transport and distance (mi) & 520 \\
Barge (40\%) & 800 \\
Rail (40\%) & 110 \\
Truck (20\%) & 24.8 \\
On-road fuel economy of LDVs fueled with & \\
bio-butanol (mi/gal gasoline equivalent) & \\
\hline
\end{tabular}

${ }^{\mathrm{a}} \mathrm{N}=$ nitrogen; $\mathrm{P}_{2} \mathrm{O}_{5}=$ phosphorus fertilizer; and $\mathrm{K}_{2} \mathrm{O}=$ potash fertilizer. 
To clearly show the energy and emission effects of bio-butanol vs. gasoline, we assumed in this study that bio-butanol is used in pure form in GVs and that butanol could achieve the same fuel economy per gallon gasoline equivalent as gasoline-powered GVs (Table 9). WTW results are expressed in a permillion-Btu fuel matrix for comparison. In reality, bio-butanol may be used in various gasoline blends. The per-million-Btu base system is more appropriate from a fuel supply perspective. Because energy and emission results are presented in Btu or grams per million Btu of fuel produced and used, the effects of differences in fuel economy are removed.
TABLE 10 U.S. Average Electricity Generation Mix Used in this Study

\begin{tabular}{lc}
\hline \multicolumn{1}{c}{ Source } & Percent of Total \\
\hline & \\
Residual oil & 2.7 \\
Natural gas & 18.9 \\
Coal & 50.7 \\
Nuclear power & 18.7 \\
Biomass & 1.3 \\
Others & 7.7 \\
\hline \multicolumn{2}{l}{ a Source: GREET, year 2010 }
\end{tabular}

\subsection{CO-PRODUCT CREDIT}

During bio-butanol production, several co-products are generated along with butanol these include acetone, DDGS, a small amount of ethanol, fatty acids (butyric acid and acetic acid), and $\mathrm{H}_{2}$ gas. On the scale that we analyzed, acetone is the major co-product of the biobutanol plant, with 82,000 metric tons produced per year. Acetone contributes to more than onehalf (by weight) of the butanol production. The bio-butanol plant also generates 253,600 metric tons of DDGS (11\% moisture) per year - the second large co-product. The yield of ethanol is relatively small (Tables 3 and 4) (similar to the level of fatty acid mixtures). Ethanol yield from $\mathrm{ABE}$ fermentation accounts for $1.5 \%$ of total $\mathrm{ABE}$ (acetone, butanol, and ethanol) by weight and only $1.2 \%$ by energy content (Btu/bu of corn) (Table 4 ). Although the fatty acids could be separated, further purified from the liquid discharge stream, and sold for use in the chemical market, the separation step has not yet been tested with ABE fermentation. In this Aspen Plus ${ }^{\circledR}$ simulation, the fatty acids were not separated and purified, and so they were not treated as coproducts.

Significant amounts of $\mathrm{H}_{2}$ and $\mathrm{CO}_{2}$ gas were produced from fermentation; these gases were used internally for gas stripping and then for maintaining anaerobic conditions for $\mathrm{ABE}$ fermentation. The $\mathrm{H}_{2}$ could be separated as a fuel product if high-purity nitrogen gas is used in place of fermentation gas. However, using such nitrogen gas to maintain anaerobic conditions and for stripping in large-scale operation could be cost prohibitive. Further studies to evaluate the engineering economics of alternative approaches for process operation while economically producing bio-butanol and hydrogen would be beneficial. In this initial attempt to address the life cycle of bio-butanol, $\mathrm{H}_{2}$ was not considered as a co-product.

We partitioned total energy and emissions into bio-butanol and the co-products by using two methods: product displacement and energy allocation. Co-product displacement (Case 2) is based on the concept of displacing the current product with the new product. In this case, bioacetone is regarded as a renewable chemical. The energy consumed and the emissions that occur during bio-acetone production displace the energy and emissions associated with petroleumbased acetone production. Energy and emission accredits from the acetone displacement are 
assigned to bio-acetone. Similarly, DDGS generated from corn butanol production contains $26.7 \%$ protein by weight, which is close to the amount of protein contained in the DDGS from the corn ethanol process. With the assumptions that the nutritional values of DDGS from the two processes are similar, the DDGS from the bio-butanol plant displaces traditional animal feed (soy protein and corn), the production pathway of which is already in place in GREET.

The limitation of using the displacement method for the bio-butanol life-cycle analysis is the large amount of acetone that is co-produced with butanol. While the main product - butanol - accounts for $63 \%$ (wt/wt) of the total product yield (acetone, butanol, and ethanol), acetone accounts for 35\% (wt/wt) (Table 3). Our previous study (Wu et al. 2005) suggested that when the share of energy co-products increases, the co-product displacement method could yield misleading results. Therefore, other partitioning methods, such as energy allocation, should be examined.

For Case 3, we applied the product energy allocation method to co-products, in which emission and energy burdens are allocated among products according to their energy output shares from the bio-butanol plant. In the energy allocation method, shares of output product energy for each product are determined according to the heating value. Energy use and associated emissions from bio-butanol production and from upstream feedstock production and transportation activities are partitioned among acetone, butanol, ethanol, and DDGS on the basis of their corresponding energy shares. This approach treats all energy products from the production process as equal, regardless of the form and quality differences among them. It also implies that all four products are energy products. The energy allocation method is applicable to this case because, of the ABE products, both butanol and ethanol are liquid fuels. Although acetone is normally regarded as a chemical solvent and feedstock, its energy content (in LHV) is, in fact, in between that of butanol and ethanol (Table 1). Furthermore, DDGS has a LHV of $8,703 \mathrm{Btu} / \mathrm{lb}$ and can be used as a solid fuel for ethanol plant operations. Several ethanol plants are currently exploring DDGS combustion or gasification, such as Corn Plus, to provide heat and power. Although the fuel

TABLE 11 Co-Product Energy Partitioning by Energy Allocation ${ }^{a}$

\begin{tabular}{cccc}
\hline $\begin{array}{c}\text { Bio- } \\
\text { Butanol }\end{array}$ & $\begin{array}{c}\text { Bio- } \\
\text { Acetone }\end{array}$ & DDGS & $\begin{array}{c}\text { Bio- } \\
\text { Ethanol }\end{array}$ \\
\hline $40 \%$ & $19 \%$ & $40 \%$ & $0.01 \%$ \\
\hline a Based on energy content.
\end{tabular}
quality of DDGS is lower than that of the liquid fuels, considering its large quantity (Table 3), use of DDGS for process heat brings energy savings and yet relaxes pressure on the already stagnant DDGS market. Table 11 presents energy shares based on product energy (in Btu) content.

We also established a case to consider the impact of overproduction of acetone (Case 4). In this case, an overabundance of acetone produced by a large-scale butanol industry would flood the acetone market, consequently losing its commercial value. Case 4 is the same as Case 2, except that it treats acetone as a waste stream (i.e., corn-acetone is not credited). This case provides an extreme scenario for bio-butanol. 


\subsection{CRADLE-TO-USER ASSESSMENT OF PETROLEUM ACETONE AND DISPLACEMENT}

\subsubsection{Petroleum Acetone and Feedstocks Production}

To evaluate the energy and emissions benefits of producing bio-acetone in a corn butanol plant, we performed a cradle-to-user analysis of petroleum-based acetone - from feedstock extraction to acetone delivery to the user site. Acetone is almost exclusively produced via cumene peroxidation, as a co-product with phenol. Its main use is as a chemical intermediate in the manufacture of acetone cyanohydrin for methyl mechacrylate, biphenol A, and adol chemicals. Direct solvent use accounts for about $30 \%$ of world demand for acetone.

A synthetic process based on hydrocarbons or derivatives is now accounted for all acetone production in the United States and nearly all production in other countries. In this process, acetone is co-produced with phenol from cumene. The yield of acetone from this process averages 2.21 units of cumene per unit of acetone by weight (Camara-Greiner 2005). Cumene is produced via alkylation of benzene with propylene under elevated temperatures and pressures in the presence of a catalyst. Upstream from cumene production, benzene is produced principally through a catalytic reforming from naphtha in a BTX (benzene, toluene, and xylene) process. The other feedstock for cumene, propylene, is one of a half dozen products from crackers receiving raw hydrocarbon (naphtha) from oil refineries, as well as natural gas. Figure 5 presents a schematic of cradle-to-user petroleum acetone production.

\subsubsection{Assumptions and Data Sources}

The cradle-to-user analysis system boundary for petroleum acetone includes resource extraction, feedstock production, acetone production, process fuel production, and associated transportation. Our petroleum acetone production data are based on the life-cycle inventory (LCI) of Eco-Profile (Boustead 2005).

Eco-Profile Reports compiled average industry data and assembled detailed environmental data for various petrochemical processes. We noted system boundary differences in the transportation and upstream fuel production stages between the Eco-Profile and the GREET database. To ensure a consistent system boundary for all seven cases with current GREET biofuel pathways, we selected feedstock production (under category "feedstock energy" in Eco-Profile) and the amount of process fuel used in production of acetone feedstocks and acetone (under category "energy content of delivered fuel" in Eco-Profile) to arrive at our energy estimate for petroleum acetone. The GREET default energy values were used for upstream fuel production (oil extraction, refining, and transportation), transport of feedstocks, and transport of acetone to users. Direct emissions from production processes (under category "process" in EcoProfile) from Eco-profile were used for our petroleum acetone cradle-to-user estimate. Emissions associated with upstream fuel production and all transportation activities were based on GREET values. Table 12 presents data sources for each life-cycle step in petroleum acetone production. 
TABLE 12 Assumptions and Data Sources of Cradle-toUser Petroleum Acetone

\begin{tabular}{|c|c|}
\hline Cradle-to-User Stage & Data Sources \\
\hline $\begin{array}{l}\text { Crude extraction for process fuel } \\
\text { Crude transport for process fuel } \\
\text { Oil refining and transport for process fuel }\end{array}$ & GREET 1.7 \\
\hline Cumene transport $^{\mathrm{a}}$ & GREET 1.7 \\
\hline Acetone production (life-cycle value) ${ }^{\mathrm{b}}$ & Eco-Profile \\
\hline \multicolumn{2}{|c|}{$\begin{array}{l}\text { a Benzene and propylene were assumed to be captive. Acetone is } \\
\text { for captive use in the acetone production facility to produce } \\
\text { acetone cyanohydrin, biphenol A, and adol chemicals. Cumene } \\
\text { is transported to acetone production facility. }\end{array}$} \\
\hline
\end{tabular}

The hypothetical corn butanol plant is located in the U.S. Corn Belt to reduce corn transportation costs. We assumed that acetone produced from the corn butanol plant would displace petroleum acetone produced in the region of Petroleum Administration for Defense Districts (PADD) II (EIA 2004). PADDs were delineated during World War II to facilitate oil allocation. PADD II includes 14 Midwest states and overlaps with the Corn Belt where most corn-based plants would operate. We identified the mass flow for cumene and acetone production and transportation in PADD II on the basis of a Chemical Economics Handbook (CEH) Marketing Research Report (Camara-Greiner 2005). In this region, 85\% of total cumene is produced from captive benzene and propylene (that is, benzene and propylene are produced and consumed on-site). The cumene is purchased by and subsequently transported to the acetone producer.

Major assumptions for cradle-to-user analysis of petroleum acetone are listed below:

- Process fuels used in the acetone pathway are electricity, oil, and natural gas.

- Electricity is purchased from the grid with the U.S. average generation mix (Table 10).

- Cumene production feedstocks (benzene and propylene) are captive in the refinery, so no transportation is associated with these feedstocks.

- The acetone production facility purchases $100 \%$ of feedstock cumene.

- Cumene needs for the acetone producer is estimated on the basis of the mass unit ratio of 2.21 units of cumene per unit of acetone (Camara-Greiner 2005). 
- Cumene is transported to the acetone production facility an average distance of 323 miles in a 1,028-Btu/ton-mi Class 8 diesel truck.

Table 13 presents the heating values used in Eco-Profile and GREET. In this assessment, energy data are expressed in LHV of Btu or $\mathrm{kWh} / \mathrm{kg}$ acetone produced. When there was a discrepancy in LHV between Eco-Profile and GREET for same fuel or chemical, the GREET value was selected to ensure consistency with the baseline fuel pathways of petroleum gasoline and corn ethanol. The energy data from Eco-Profile are converted according to the ratio of LHV Eco-Profile/LHV GREET (Table 13).

TABLE 13 Low-Heating-Value Comparison for this Study ${ }^{a}$

\begin{tabular}{lcccc}
\hline & $\begin{array}{c}\text { GREET } \\
\text { (Btu/gal, }\end{array}$ & $\begin{array}{c}\text { Eco-Profile } \\
(\mathrm{MJ} / \mathrm{kg})\end{array}$ & $\begin{array}{c}\text { Eco-Profile } \\
(\mathrm{Btu} / \mathrm{gal}, \\
\mathrm{Btu} / \mathrm{scf})\end{array}$ & $\begin{array}{c}\text { Ratio LHV } \\
\text { Eco/GREET }\end{array}$ \\
\hline Fuel & Btu/scf) & & & \\
Fuel oil & 140,353 & 40.5 & 144,176 & 1.03 \\
NG & 983 & 48.16 & 1,005 & 1.02 \\
\hline
\end{tabular}

${ }^{a}$ Unit for fuel oil is Btu/gal; unit for natural gas is Btu/scf.

\subsubsection{Petroleum Acetone Displacement}

We assumed that the corn-based butanol plant would be built near a corn farm in the Midwest PADD II region and operated at a production scale of 150,000 metric tons of biobutanol per year. With a mass production ratio of $0.56 \mathrm{lb}$ of bio-acetone per pound of biobutanol, this facility could yield 82,461 metric tons of bio-acetone annually $-16 \%$ of the total acetone production in PADD II and 4\% nationwide. We assumed that bio-acetone would be transported to acetone consumers via train (500 miles) and truck (100 miles) within PADD II.

In the co-product displacement approach (Case 2), petroleum acetone is displaced by corn-based acetone from cradle to user. The displacement is carried out in the following sequence: the cradle-to-gate results of petroleum acetone (as illustrated in Figure 5) were first subtracted from the WTW results of bio-butanol, and then the energy or emissions values associated with bio-acetone transportation from the bio-butanol plant to the acetone user were added. 


\section{Corn-Acetone}

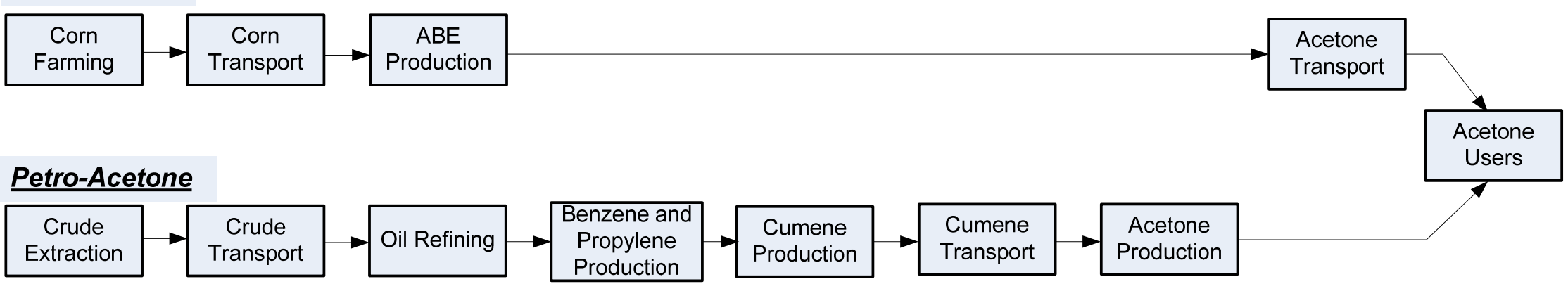

FIGURE 5 System Boundaries for Cradle-to-User Pathway of Fossil-Based Acetone and Corn-Based Acetone 


\section{RESULTS AND DISCUSSION}

\subsection{ENERGY CONSUMPTION AND GHG EMISSIONS}

Corn-derived butanol achieves substantial fossil energy savings (39-56\%) compared with gasoline ([Cases 3 and 2], Figure 6) on a life-cycle basis. In Cases 2 and 3, bio-butanol production contributes to a positive energy balance (defined as fossil energy used in gasoline production minus fossil energy used in bio-butanol production). Without acetone credit as in Case 4, in which acetone is regarded as a waste, bio-butanol production is not an option for fossil energy savings.

The primary fuel consumed in the bio-butanol life cycle is natural gas, followed by petroleum oil and coal (Figure 6). Although electricity generation uses 50\% of coal (Table 10), the amount of electricity required is relatively small (Table 8 ), and so only $9-17 \%$ of total fossil energy use is from coal (Cases 3 and 2). A life-cycle fossil energy breakdown (Figure 7) indicates that about three-fourths of the fossil fuel is spent in the butanol production plant (73\%). Corn cultivation accounts for a total of $23 \%$ of WTW fossil energy (12\% for agricultural chemical and fertilizer manufacturing and $11 \%$ for farming operations). In the butanol plant, the majority of natural gas demand comes from the process steam requirement (Table 5), which leads to 115,000 Btu per gallon of butanol produced - approximately three times that of corn ethanol production before co-products are allocated. As we pointed out earlier, this estimate tends to be conservative because it did not reflect the lower heating requirement for DDGS drying in the bio-butanol plant. The water requirement in biological fuel production drives the energy balance in the plant. A higher concentration of product in fermentation reduces energy needs for product concentrating in subsequent process steps. Historically, improvement of ethanol concentration in a fermentor from $\sim 8 \%$ in 1980 s to $20 \%$ at present demonstrates, in part, the lower energy cost in ethanol plant operation. The ABE fermentation process evaluated in this study achieved a concentration of $19 \%$ (wt/wt) of total solvents (ethanol, butanol, and acetone) in a fermentor. With rapid in-situ removal of solvent by gas stripping, the process is able to increase feed concentration to improve production rate while minimizing butanol inhibition. Although using concentrated feed in fermentation effectively reduces about $14 \%$ of the steam requirement (Table 5), solids concentration in the fermentor - an important issue in process development and operation — remains a constraint.

Vehicles fueled by bio-butanol achieve small to moderate reductions in GHG emissions relative to gasoline vehicle on a WTW basis in Cases $2(8 \%$, displacement ) and $3(32 \%$, energy allocation) (Figure 8). For every million Btu of bio-butanol used in place of one million Btu of gasoline, 8-32 kg of GHG emissions could be avoided (Cases 2 and 3). The GHG emissions profile for the bio-butanol production option in this study is similar to that of corn ethanol. Of total GHG emissions in the bio-butanol WTW cycle, over $70 \%$ by weight of the GHGs are from $\mathrm{CO}_{2}$, less than $5 \%$ is from methane, and the remaining $18-21 \%$ is from $\mathrm{N}_{2} \mathrm{O}$ (Figure 9). Natural gas consumption in butanol plant is the major cause of GHG emission.

We assumed that vehicles fueled by bio-butanol would offer performance similar to that of vehicles fueled by gasoline. We have not found any vehicle testing data to confirm this 
assumption. Vehicle testing with butanol should be conducted to evaluate butanol's performance in vehicles under realistic driving conditions.

\subsection{EFFECT OF ACETONE CO-PRODUCT CREDIT}

Energy partitioning for co-products has a significant effect on overall energy use and associated GHG emissions. The three cases that we examined (2, 3, and 4) presented different options for acetone. When acetone is regarded as a fuel, and credit is allocated on the basis of product energy content (Case 3), the WTW analysis yields moderate fossil energy and GHG emissions benefits for bio-butanol. When acetone is used as a renewable chemical to displace petroleum acetone via the displacement method (Case 2), the results of analysis show $17 \%$ savings in fossil fuel (Figure 6) and small reductions in GHG emissions (Figure 8). However, treating acetone as a waste stream (Case 4) resulted in an increase of almost one million Btu in fossil energy and 40,000 $\mathrm{g}$ of GHG emissions (compared with gasoline) for each million Btu of bio-butanol produced. The difference is largely attributable to the acetone credit. Feedstocks for petroleum-based acetone production (propylene and benzene [Figure 5]) are produced from naphtha and natural gas - 100\% fossil feedstock (Lacson et al. 2005). Another factor is the high yield of acetone from the ABE process: $0.56 \mathrm{lb}$ acetone per pound of butanol. These two factors suggest that a significant portion of fossil energy use in petroleum acetone production will be regarded as a credit when bio-acetone displaces fossil acetone, which eventually leads to a small fossil energy value (Figure 6).

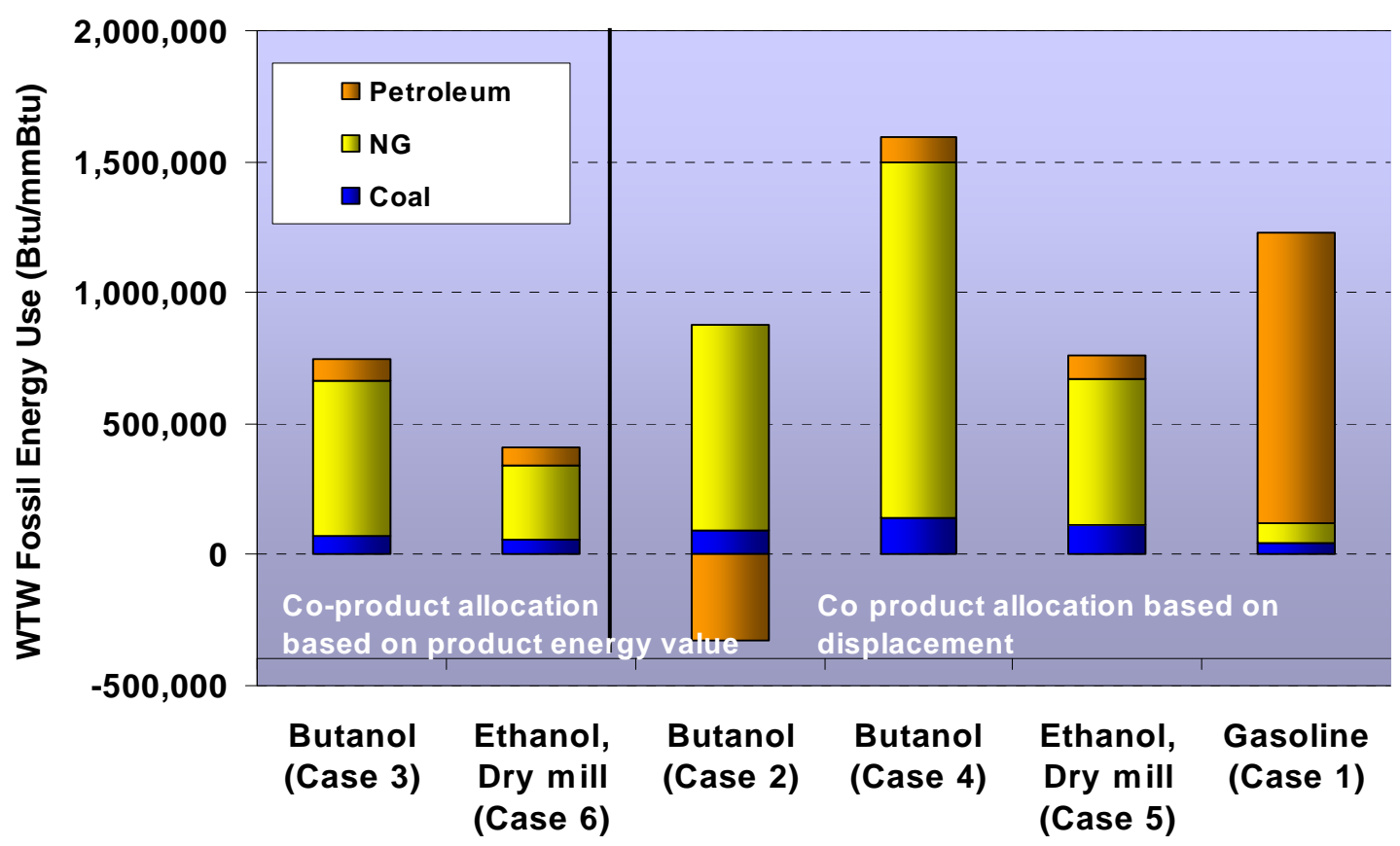

FIGURE 6 Well-to-Pump Fossil Energy Breakdown for Bio-Butanol and Corn Ethanol Compared with Gasoline, Using Different Co-Product Allocation Methods (negative value indicates fossil energy avoided) 


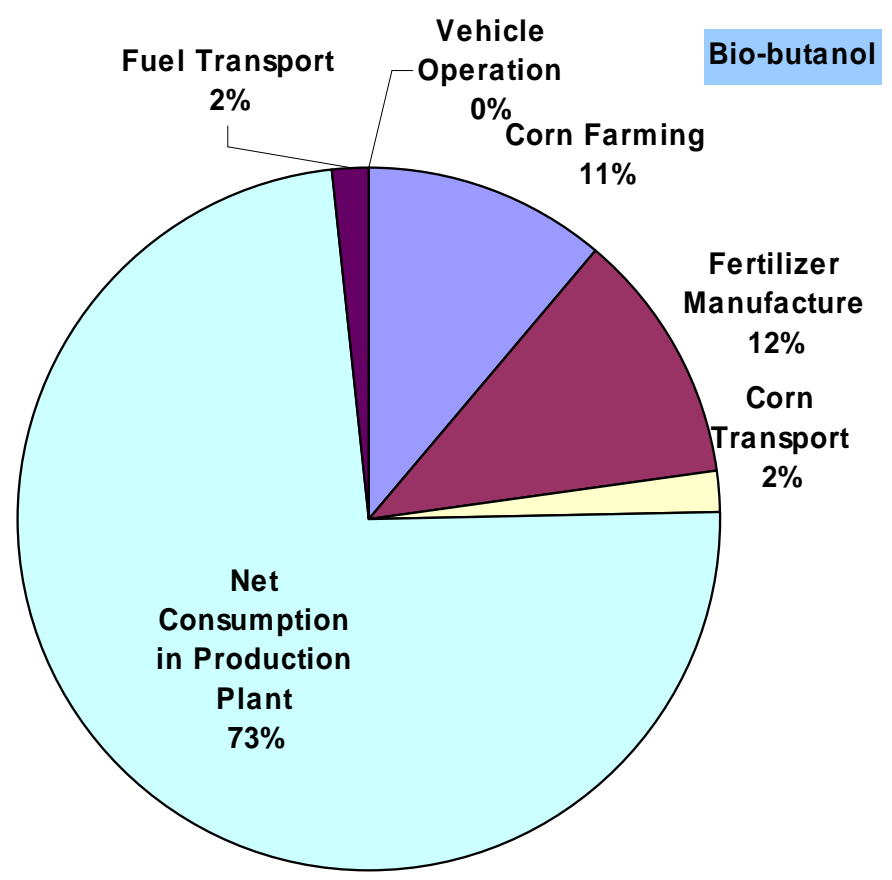

FIGURE 7 Breakdown of Fossil Energy Use in Various Stages of Fuel Life Cycle for Corn-Based Butanol (Case 3)

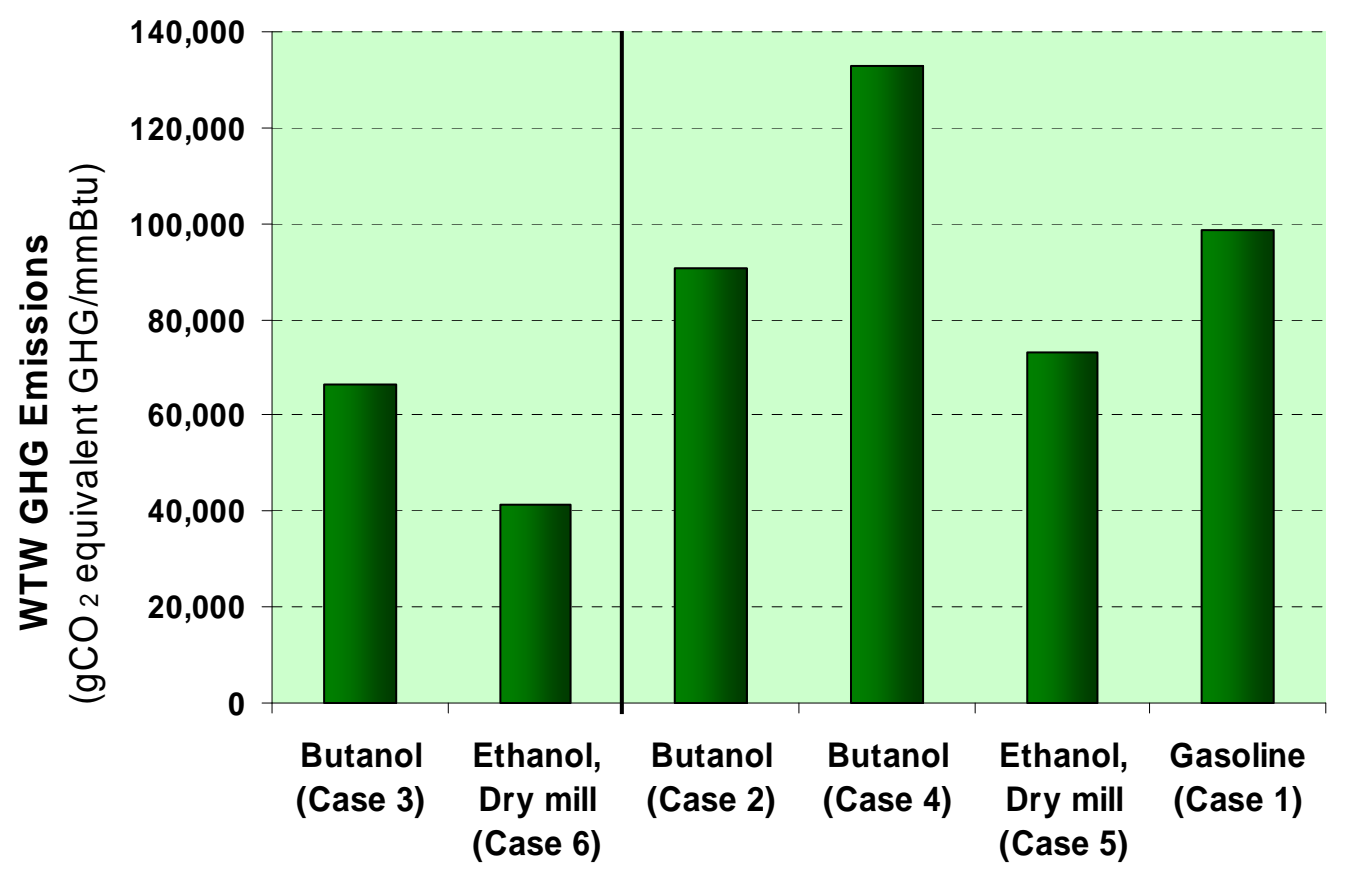

FIGURE 8 Life-Cycle GHG Emissions of Bio-Butanol and Ethanol Compared with Gasoline, Using Different Co-Product Allocation Methods 


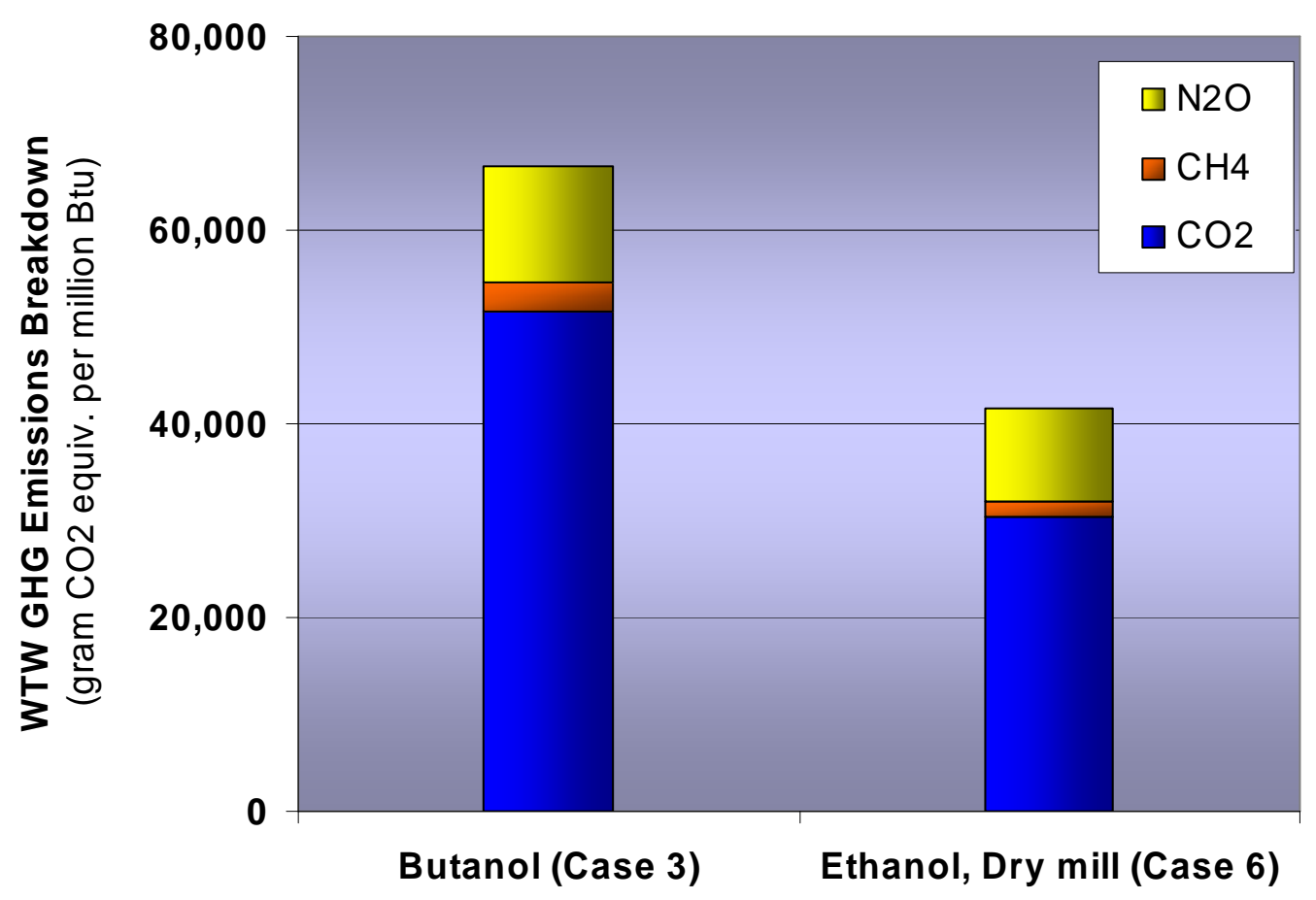

FIGURE 9 Life-Cycle GHG Emission Breakdown for Bio-Butanol and Ethanol (Energy Allocation)

The displacement method provides significant benefits in terms of reductions in the use of fossil energy (Figure 6), but relatively small reductions in GHG emissions (Figure 8). The main reason for this phenomenon is that petroleum acetone production extracts carbon from a fossil resource and transforms the carbon to another bounded form (chemical), with net GHG emissions generated from consumption of the process fuel. In its life cycle, petroleum acetone is primarily used as a chemical/feedstock with a fraction as solvent. Although a small amount of carbon embedded in petroleum acetone may escape to the atmosphere through volatilization during product application (i.e., use as solvent), the majority ultimately ends up as a solid/liquid chemical in a bound form rather than being emitted to the air as $\mathrm{CO}_{2}$. By displacing petroleum acetone with bio-acetone in this case, the life-cycle reductions in fossil energy use do not translate to benefits in terms of GHG emissions.

\subsection{COMPARISON OF BIO-BUTANOL WITH CORN ETHANOL}

The ABE process simulated in this study appears to be as efficient in producing acetone, butanol, and ethanol on a weight basis as current corn dry mills (Table 14). Measured by gallon or gram of $\mathrm{ABE}$, the yields from the $\mathrm{ABE}$ process are similar to ethanol yields from a conventional dry mill. As a rule of thumb in ethanol produced from corn dry milling, one-third of the feed mass goes to ethanol, one-third is left in DDGS, and one-third is emitted as $\mathrm{CO}_{2}$. The 
TABLE 14 Acetone, Butanol, and Ethanol Outputs from Corn Compared with Ethanol from Conventional Corn Mills

\begin{tabular}{|c|c|c|c|c|c|}
\hline & \multicolumn{4}{|c|}{ Corn Butanol Plant } & \multirow{2}{*}{$\begin{array}{l}\text { Ethanol } \\
\text { from Corn } \\
\text { Dry Mills }\end{array}$} \\
\hline & Acetone & Butanol & Ethanol & Total & \\
\hline Btu/bu corn & 69,525 & 149,267 & 2,828 & $\begin{array}{l}221,620 \text { (with } \\
\text { acetone); 152,095 } \\
\text { (without acetone) }\end{array}$ & 198,458 \\
\hline $\mathrm{Gal} / \mathrm{bu} \operatorname{corn}^{\mathrm{a}}$ & 0.87 & 1.50 & 0.04 & 2.40 & 2.60 \\
\hline $\mathrm{gC} / \mathrm{g}$ corn $^{\mathrm{b}}$ & 0.074 & 0.137 & 0.003 & 0.214 & 0.172 \\
\hline
\end{tabular}

ABE process examined in this study follows almost the same rule: one-third of the feed mass ends up in the products (acetone, butanol, and ethanol), one-third remains in DDGS, and about one-third $(30 \%)$ is emitted as $\mathrm{CO}_{2}$ (Table 15) (the remaining $\sim 3 \%$ ends up in fatty acids [butyric and acetic acids] and losses).

Because acetone is not used as a fuel at present, net fuel production (butanol and ethanol) is small. A typical dry mill can deliver $2.72 \mathrm{gal} / \mathrm{bu}$ of fuel ethanol, or $2.6 \mathrm{gal} / \mathrm{bu}$ of undenatured ethanol, which is $\sim 1.1$ gal more than the butanol and ethanol yield together from the ABE process (1.54 gal/bu) (Table 14). On the other hand, butanol contains 30\% more energy (LHV) than ethanol (Table 1) by volume. When we take fuel energy yield into consideration, each bushel of corn could generate nearly 152,000 Btu of liquid fuels from the ABE process (butanol and ethanol together), while the same bushel delivers 198,000 Btu of liquid fuels (undenatured ethanol) from the conventional ethanol dry mill (46,000 Btu more than the bio-butanol option). Hence, from a liquid fuel production perspective, the ABE process option does not offer an increase in renewable fuel production, in comparison with conventional corn ethanol production.

Process fuel use for ABE production could be a major hurdle, as indicated in Table 16. A bushel of corn requires $82 \%$ more steam and $34 \%$ more electricity to produce ABE from a biobutanol plant than to produce ethanol from a corn dry mill. If the first corn butanol plant is built from an existing corn dry mill that has been retrofitted, the implication is that operation cost will be high. To build a new corn butanol plant, capital cost may be lower because of the reduced footprint in fermentation and downstream processing relative to the existing dry mill, but the plant would have increased process fuel cost - especially given the current price for natural gas. 
TABLE 16 Process Fuel Use in Bio-Butanol and Ethanol Production Plant

\begin{tabular}{lccc}
\hline \multicolumn{1}{c}{ Fuel } & Bio-butanol Plant & Ethanol Dry Mill & $\begin{array}{c}\text { Ratio of Butanol } \\
\text { to Ethanol }\end{array}$ \\
\hline $\begin{array}{l}\text { Natural gas } \\
\text { (Btu/bushel of corn) }\end{array}$ & 172,108 & 94320 & 1.82 \\
$\begin{array}{l}\text { Electricity } \\
(\mathrm{kW} / \text { bushel of corn) }\end{array}$ & 2.63 & 1.97 & 1.34 \\
\hline
\end{tabular}

Another concern is the feedstock supply for bio-butanol. The current ABE process shares the same starch-based feedstocks with conventional corn ethanol. Development of bio-butanol through the $\mathrm{ABE}$ process could take limited feedstocks away from conventional corn ethanol production. R\&D efforts in bio-butanol may need to be directed toward identifying new feedstocks and process technologies. In fact, Qureshi (2007) recently reported on a study using cellulosic biomass as feedstock for bio-butanol production via the $\mathrm{ABE}$ process. Because $\mathrm{ABE}$ fermentation is from glucose, the results of ongoing $\mathrm{R} \& \mathrm{D}$ on cellulosic pretreatment for cellulosic ethanol could be applied to the ABE process.

\subsection{CRADLE-TO-USER COMPARISON OF BIO-ACETONE WITH PETROLEUM ACETONE: ISSUES AND CONCERNS}

Use of bio-acetone to displace petroleum acetone shows promising energy and environmental benefits (Figure 10), from a life-cycle perspective. Conventional acetone production is a fossil-energy-intensive process. By producing acetone from corn, manufacturers could save a significant amount of total fossil energy - up to $71 \%$ relative to petroleum-based acetone. The renewable acetone achieves energy savings of $91 \%$ for petroleum and $58 \%$ for natural gas. Figure 11 further shows the life-cycle fossil energy distribution between the two. The majority of fossil energy use shifts from feedstocks $(57 \%)$ in the petroleum acetone production process to acetone production $(70 \%)$ in the corn acetone production process.

Bio-acetone in this study is produced from corn - a renewable agricultural resource that absorbs atmospheric $\mathrm{CO}_{2}$ during its growth. The carbon in $\mathrm{CO}_{2}$ is converted to organic carbon in the corn and is further transformed and embedded in acetone through the ABE process. Therefore, we allocated a renewable carbon credit to bio-acetone for the carbon embedded in corn. As illustrated in Figure 12, a net carbon sequestration would occur from cradle to user. GHG emissions would be much higher - about $500 \mathrm{~g} / \mathrm{lb}$ acetone produced, if the carbon in acetone is from non-renewable sources.

Although bio-acetone production results in positive WTW energy benefits and decreased GHG burdens, several issues and concerns need to be addressed. In 2005, a total of 1.9 million metric tons of acetone was produced in the United States (Camara-Greiner 2005). PADD II, which overlaps with the U.S. corn belt, would most likely to be the location for corn-based 
butanol plants. Production of petroleum acetone in this region in 2005 was 505,000 metric tons, representing $26 \%$ of total U.S. production. If bio-acetone were produced from a single simulated bio-butanol plant located in this region, the volume of bio-acetone would be about $16 \%$ of the total petroleum acetone production in the region and $4 \%$ nationwide. Furthermore, assuming that total bio-butanol production levels could reach a quarter of the production level of corn ethanol of 4.9 billion gallons (2006), the amount of corn feed used for bio-butanol production could generate 676 million gallons of bio-butanol and 391 million gallons (1.2 million metric tons) of bio-acetone. At this production scale, the acetone market would be flooded with both bio- and petroleum acetones, dramatically decreasing the market value of acetone. Thus, one may argue that acetone should be treated as a waste stream (as we did in Case 4). Aside from the fossil energy and GHG benefits (within WTW analysis boundaries) that may result from the production of bio-butanol, we should consider the emission of liquid acetone into the environment if acetone is treated as a waste stream. On the basis of a value of $0.074 \mathrm{~g}$ of carbon generated in acetone from each gram of corn, if all of the carbons contained in acetone were converted to gaseous $\mathrm{CO}_{2}$, approximately $6,900 \mathrm{~g}$ of $\mathrm{CO}_{2}$ could be emitted to the atmosphere per bushel of processed corn. Acetone-containing water in such high volumes could become a major source of atmospheric VOC and $\mathrm{CO}_{2}$ emissions.

Unfortunately, the outlook for replacement of petro-chemicals with bio-chemicals is far from clear. Petroleum acetone is currently generated as a by-product during phenol production from cumene. On average, $0.61 \mathrm{lb}$ of acetone is obtained per pound of phenol produced (SRI Consulting 2005). The United States consumed \$2.1 million metric tons of phenol in 2004 (SRI Consulting 2007). Worldwide, the consumption of phenol grows at a rate of $4.1 \%$ per year. As demand for phenol continues to rise, petroleum acetone will be produced with or without the presence of bio-acetone. In the ABE process studied, the bio-acetone is also a co-product. New technologies/processes that significantly reduce the acetone that results from phenol and $\mathrm{ABE}$ production are therefore needed. In fact, at the time of this study, DuPont was making considerable progress in molecular biology, which led to a patent award for a recombinant bacterium that produces butanol exclusively from biological feedstocks (DuPont 2007). Other potential research directions include exploring the use of acetone as a fuel blend and as a feedstock for new chemicals. 


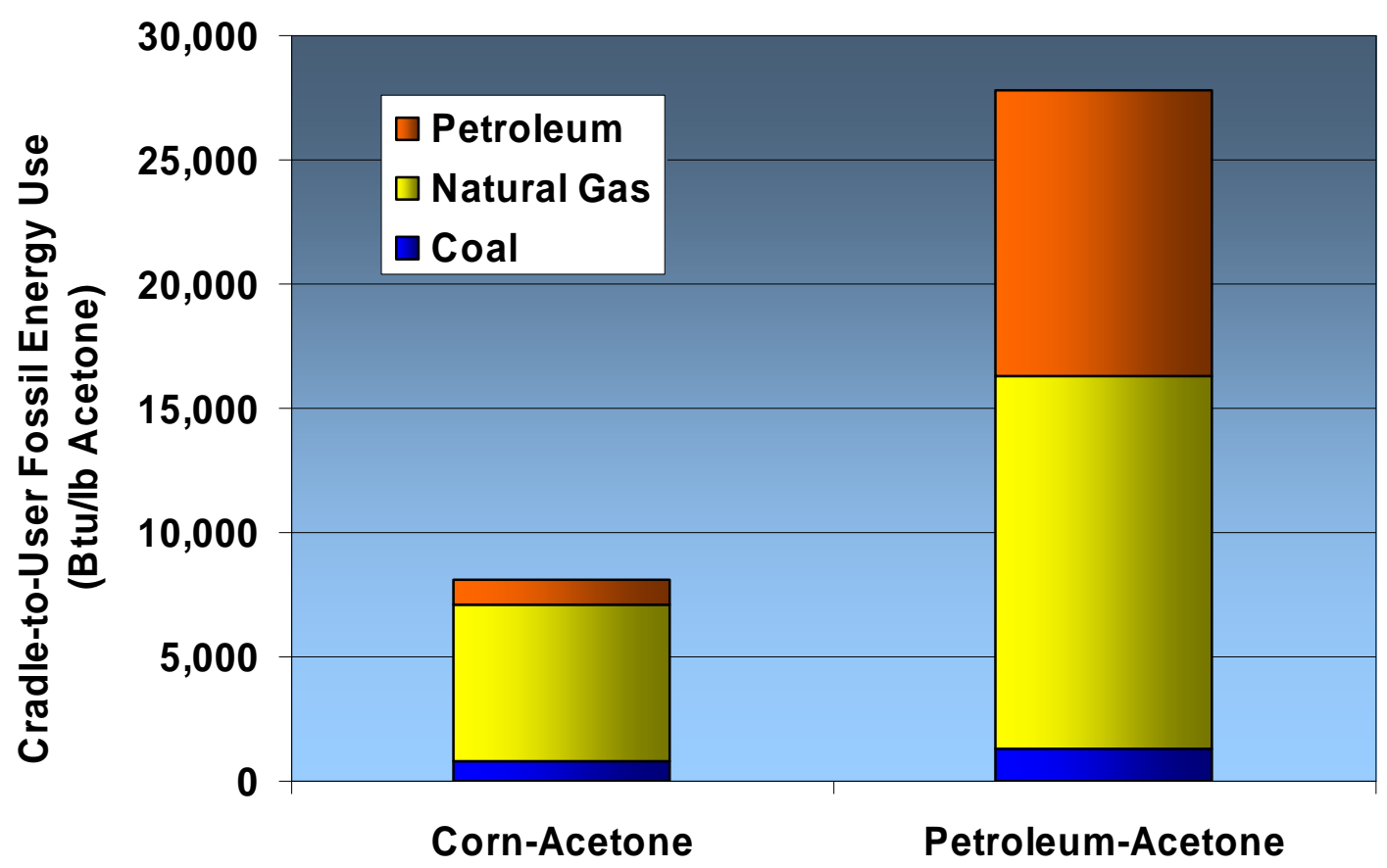

FIGURE 10 Fossil Energy Use Based on the Production of Bio-Acetone Compared with Fossil Energy Use Based on the Production of Petroleum Acetone 
8127 Btu of fossil per Ib of corn acetone

a) bio-Acetone

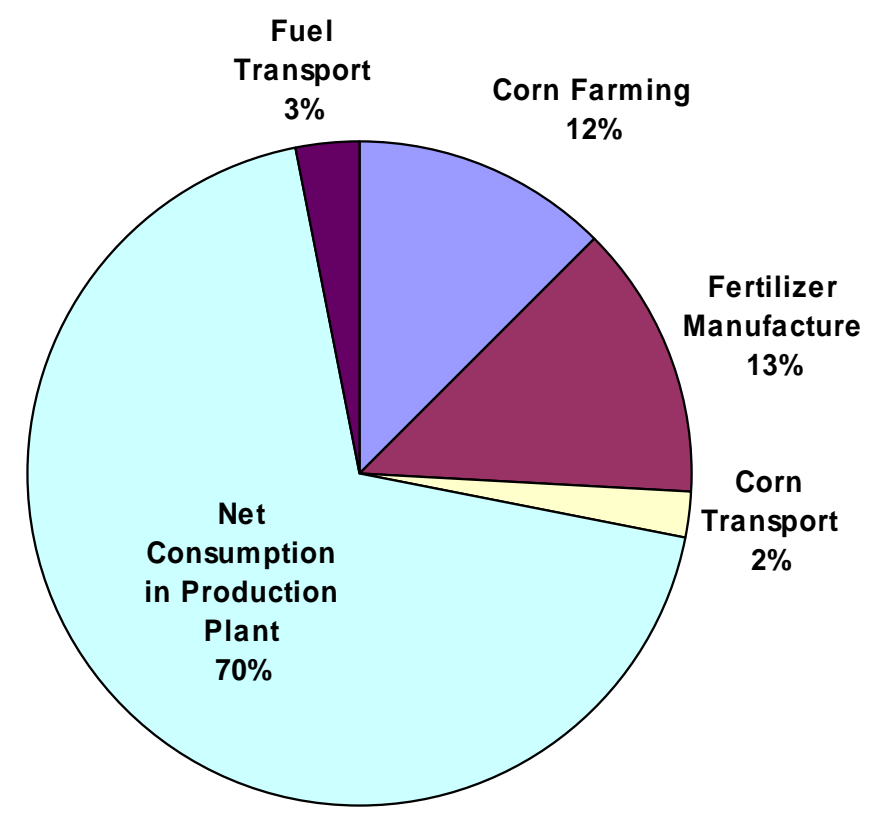

27818 btu of fossil per lb of acetone

Feedstock and acetone transportation

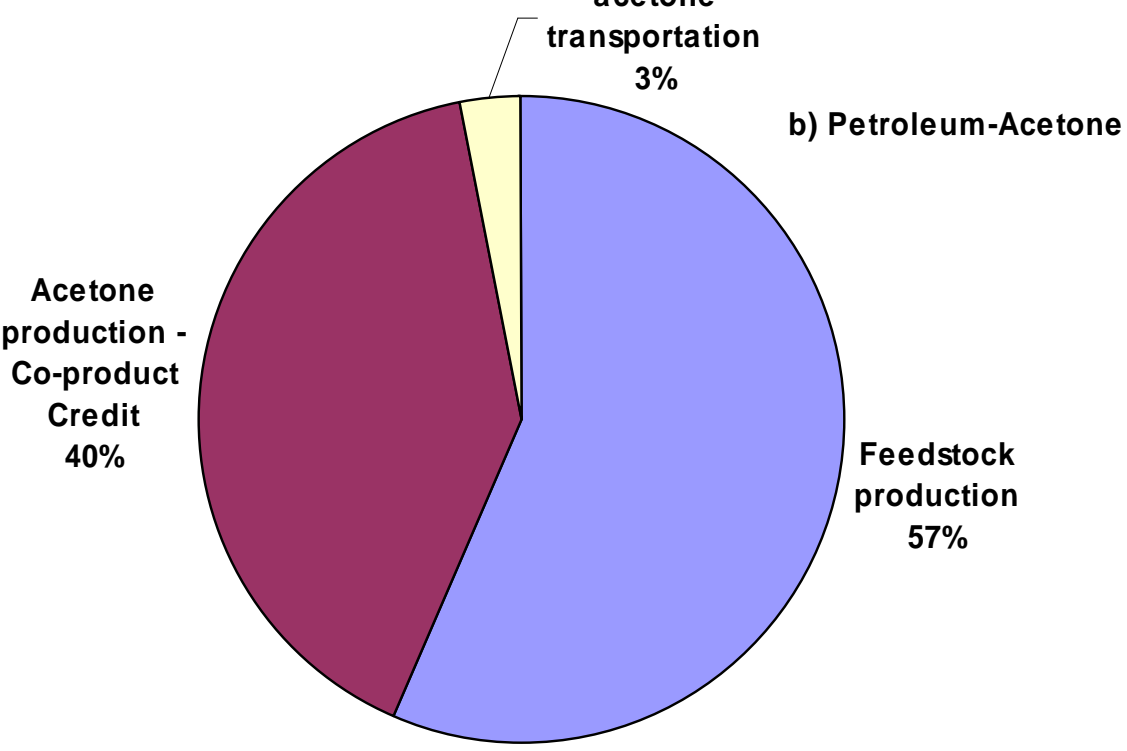

FIGURE 11 Fossil Energy Consumption Breakdown for

(a) Bio-Acetone and (b) Petroleum Acetone 


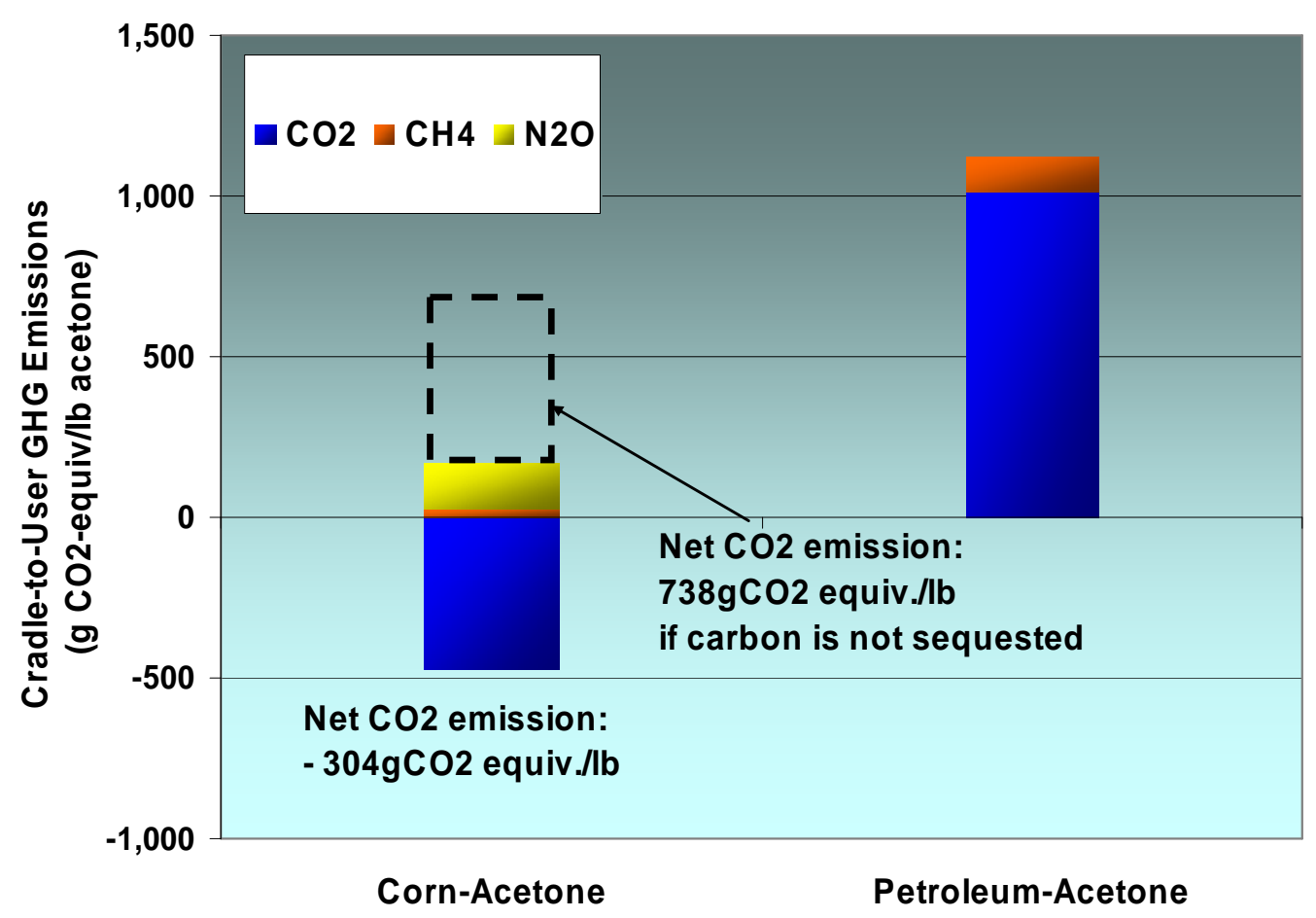

FIGURE 12 GHG Emissions Generated or Avoided by Bio-Acetone Production Compared with Petroleum Acetone Production 


\section{CONCLUSIONS}

Our conclusions, based on the results of our study, include the following:

- Corn-based butanol, produced by means of the current ABE process, could offer substantial fossil energy savings and moderate reductions in GHG emissions relative to petroleum gasoline on a WTW basis, when co-products are credited by energy allocation.

- The energy benefits associated with bio-butanol are significant when coproduct corn-acetone is credited with displacement method.

- When acetone is credited by energy allocation, life-cycle energy benefits for corn butanol are less promising than those of corn ethanol generated from conventional dry milling processes. GHG emissions generated from biobutanol life cycle are higher than those generated from corn ethanol.

- From a liquid fuel production standpoint, the ABE process examined may not be as effective as conventional corn ethanol production in that it produces less liquid fuel (on an energy basis) per bushel of corn than the corn ethanol process, in addition to increased process fuel use in the production plant.

- The impacts of corn-acetone (produced via the ABE process) on the acetone market need to be carefully examined, and new uses for bio-acetone need to be explored. 


\section{REFERENCES}

Boustead, I., 2005, "Eco-Profiles of the European Plastic Industry: Acetone," Plastics Europe, March, available at http://www.plasticseurope.org/Content/Default.asp?PageID=392\#, accessed Dec. 2006.

Brinkman, N., M. Wang, T. Weber, and T. Darlington, 2005, GM Study: Well-to-Wheels Analysis of Advanced Fuel/Vehicle Systems - A North American Study of Energy Use, Greenhouse Gas Emissions, and Criteria Pollutant Emissions, May, http://www.transportation.anl.gov/pdfs/TA/339.pdf.

Collins, K., 2007, The New World of Biofuels: Implications for Agriculture and Energy, Presented at EIA Energy Outlook, Modeling, and Data Conference, March. Washington D.C.

Conti, J., 2007, Annual Energy Outlook 2007, presentation at EIA Energy Outlook, Modeling, and Data Conference, March, Washington D.C.

Dadgar, A.M., and G.L. Foutch, 1988, "Improving the Acetone-Butanol Fermentation Process with Liquid-Liquid Extraction," Biotechnology Progress 4: 36-39.

DuPont, 2007, Fermentive Production of Four Carbon Alcohols, World Patent Application WO/2007/041269; USPTO PCT/US2006/038007.

EIA: see Energy Information Administration

Energy Information Administration, 2004, http://www.eia.doe.gov/pub/oil_gas/petroleum/ analysis_publications/oil_market_basics/paddmap.htm; accessed May 15, 2007.

Energy Information Administration, 2007, Annual Energy Outlook 2007, DOE/EIA-0383(2007), available at http://www.eia.doe.gov/oiaf/aeo/pdf/0383(2007).pdf, accessed May 23, 2007.

Ezeji, T.C., N. Qureshi, and H.P Blaschek, 2004, “Acetone Butanol Ethanol (ABE) Production from Concentrated Substrate: Reduction in Substrate Inhibition by Fed-Batch Technique and Product Inhibition by Gas Stripping," Appl. Microbiol. Biotechnol. 63: 653-658.

Ezeji, T.C., P.M. Karcher, N. Qureshi, and H.P Blaschek, 2005, "Improving Performance of a Gas-Stripping-Based Recovery System to Remove Butanol from Clostridium Beijerinckii Fermentation, Bioprocess Biosyst. Eng. 27: 207-214.

Guibet, J.-C., 1997, Carburants et Moteurs: Technologies, Energie, Environnement, Publication de l'Institut Français du Pétrole, ISBN 2-7108-0704-1.

Heckl, I., Z. Kovacs, F. Friedler, L.T. Fan, and J. Liu, 2006, "Algorithmic Synthesis of an Optimal Separation Network Comprising Separators of Different Classes," Chemical Engineering and Processing, doi:10.1016/j.cep.2006.06.013. 
Huang, W.C., D.E. Ramey, and S.T. Yang, 2004, "Continuous Production of Butanol by Clostridium Acetobutylicum Immobilized in a Fibrous Bed Bioreactor," in Applied Biochemistry and Biotechnology - Part A: Enzyme Engineering and Biotechnology 113-116: 887-898.

Intergovernmental Panel on Climate Change (IPCC), 2001, Climate Change 2001: the Scientific Basis, Technical Summary of the Group I Report.

Intergovernmental Panel on Climate Change (IPCC), 2007, Working Group I: The Physical Basis of Climate Change, IPCC WG1 AR4 report, available at http://ipcc-wg1.ucar.edu/wg1/ wg1-report.html, accessed May 23, 2007.

IPCC: see Intergovernmental Panel on Climate Change

Kwiatkowski, J.R., McAloon, A.J., Taylor, F., Johnston, D. 2006, Modeling the process and costs of the production of fuel ethanol by the corn dry-grind process. Industrial Crops and Products. V.23, Issue 3, p.288-296.

Lacson, J.G., 2004, "Propylene," in Chemical Economics Handbook (CEH) Marketing Research Report, SRI Consulting, Menlo Park, Calif.

Liu, J., 2003, Downstream Process Synthesis for Biochemical Production of Butanol, Ethanol, and Acetone from Grains, PhD Dissertation, Kansas State University, Manhattan, KS.

Liu, J., L.T. Fan, P. Seib, F. Friedler, and B. Bertok, 2004, "Downstream Process Synthesis for Biochemical Production of Butanol, Ethanol, and Acetone from Grains: Generation of Optimal and Near Optimal Flowsheets with Conventional Operating Units," Biotechnol. Prog. 20, $1518-1527$.

Liu, J., L.T. Fan, P. Seib, F. Friedler, and B. Bertok, 2006, "Holistic Approach to Process Retrofitting: Illustration with Downstream Process for Biochemical Production of Organics," Ind. Eng. Chem. Res. 45: 4200-4207.

Marlatt, J.A., and R. Datta, 1986, "Acetone-Butanol Fermentation Process Development and Economic Evaluation," Biotechnology Progress 2: 23-28.

McAloon, A., 2006, Shelled Corn to Ethanol Process Energy Analysis, Aspen + ${ }^{\circledR}$ MGY Dry Grind Ethanol Process Model, ERRC/ARS/USDA

Morey, V., et al., 2006, Characterization of Feed Streams and Emissions from Biomass Gasification/Combustion at Fuel Ethanol Plants, American Society of Agricultural and Biological Engineers (ASABE) Presentation Paper Number 064180, July, Portland, Ore.

Mueller, S., and J. Cuttia, 2006, Research Investigation for the Potential Use of Illinois Coal in Dry Mill Ethanol Plants, prepared by the Energy Resources Center at University of Illinois at Chicago, for the Illinois Clean Coal Institute and the Illinois Department of Commerce and Economic Opportunity, Oct. 
Mueller, S., 2006, Energy Resources Center, University of Illinois at Chicago, Chicago, Ill., personal communication to May Wu of Argonne National Laboratory, Argonne, Ill.

Natural Resources Canada, 2007, "The Addition of Bio-Butanol to GHGenius and a Review of the GHG Emissions from Diesel Engines With Urea SCR", NRC Report, prepared by (S\&T) ${ }^{2}$ Consultants, BC, Canada.

Parekh, M., J. Formanek, and H.P. Blaschek, 1999, "Pilot-Scale Production of Butanol by Clostridium Beijerinckii BA 101 Using a Low-Cost Fermentation Medium Based on Corn Steep Water," App. Microbiol. Biotechnol. 51: 152-157.

Qureshi, N., and H.P. Blaschek, 1999, Economics of Butanol Fermentation Using Hyper-Butanol Producing Clostridium Beijerinckii BA 101," Trans. Institution of Chemical Engineers 78 (Part C): 139-144.

Qureshi, N., and H.P. Blaschek, 2001a, "ABE Production from Corn: A Recent Economic Evaluation,” Journal of Industrial Microbiology \& Biotechnology 27: 292-297.

Qureshi, N., and H.P. Blaschek, 2001b, "Recovery of Butanol from Fermentation Broth by Gas Stripping," Renewable Energy 22: 557-564.

Qureshi, N., 2007, Bioconversion of Agricultural Residues to Butanol: Simultaneous Saccharification, Fermentation, and Product Recovery, Presentation at the $29^{\text {th }}$ Symposium on Biotechnology for Fuels and Chemicals, Denver, CO.

Roddy, W., 2006, Dry Mill Ethanol Plants: Environmental Impacts and Future Growth, ICM, Presented at Governors' Ethanol Coalition, Feb.

SRI Consulting, 2005, Chemical Economics Handbook (CEH) Marketing Research Report, Menlo Park, Calif.

SRI Consulting, 2007, Chemical Economics Handbook (CEH) Marketing Research Report, Menlo Park, Calif.

White and Johnson, 2003, Corn: Chemistry and Technology, $2^{\text {nd }}$ edition.

Wu, M., Y. Wu, M. Wang, 2005, Mobility Chains Analysis of Technologies for Passenger Cars and Light-Duty Vehicles Fueled with Biofuels: Application of the GREET Model to the Role of Biomass in America's Energy Future (RBAEF) Project, Argonne National Laboratory Report, May, available at http://www.transportation.anl.gov/pdfs/TA/344.pdf. 
APPENDIX 


\section{APPENDIX}

\section{A1 PARAMETERS FOR CORN BUTANOL LIFE-CYCLE ANALYSIS}

\section{Corn Farming}

Energy Use

Fertilizer Use

Nitrogen:

$\mathrm{P}_{2} \mathrm{O}_{5}$ :

$\mathrm{K}_{2} \mathrm{O}$ :

$\mathrm{CaCO}_{3}$ :

Pesticide Use

Herbicide:

Insecticide:

Corn Transportation

From Field to Stacks

Truck

Share:

Distance:

From Stacks to Plants

Truck

Share: $\quad 100 \%$

Distance: $\quad 40 \mathrm{mi}$

\section{Butanol Production}

Energy Use

$\begin{array}{ll}\text { Thermal Energy } & 115,114 \mathrm{Btu} / \mathrm{gal} \mathrm{BuOH} \\ \text { Electricity } & 1.76 \mathrm{kWh} / \mathrm{gal} \mathrm{BuOH}\end{array}$

Yield
$22,500 \mathrm{Btu} / \mathrm{bu}$

$420 \mathrm{~g} / \mathrm{bu}$

$149 \mathrm{~g} / \mathrm{bu}$

$174 \mathrm{~g} / \mathrm{bu}$

$1,202 \mathrm{~g} / \mathrm{bu}$

$8.10 \mathrm{~g} / \mathrm{bu}$

$0.68 \mathrm{~g} / \mathrm{bu}$
GREET corn-EtOH pathway

GREET corn-EtOH pathway GREET corn-EtOH pathway GREET corn-EtOH pathway GREET corn-EtOH pathway

GREET corn-EtOH pathway GREET corn-EtOH pathway
GREET corn-EtOH pathway GREET corn-EtOH pathway

GREET corn-EtOH pathway GREET corn-EtOH pathway

$\begin{array}{lll}\text { Butanol } & 1.50 \mathrm{gal} / \mathrm{bushel} & \text { see report } \\ \text { Acetone } & 3.80 \mathrm{lb} / \mathrm{gal} \mathrm{BuOH} & \text { see report } \\ \text { DDGS } & 11.66 \mathrm{lb} / \mathrm{gal} \mathrm{BuOH} & \text { see report }\end{array}$

Butanol Transportation and Distribution

Transportation

$\begin{array}{lll}\begin{array}{l}\text { Barge } \\ \text { Share: }\end{array} & 40 \% & \\ \text { Distance: } & 520 \mathrm{mi} & \begin{array}{l}\text { see report } \\ \text { see report }\end{array} \\ \text { Rail } & & \\ \text { Share: } & 40 \% & \text { see report } \\ \text { Distance: } & 800 \mathrm{mi} & \text { see report } \\ \text { Truck } & & \text { see report } \\ \text { Share: } & 20 \% & \text { see report } \\ \text { Distance: } & 110 \mathrm{mi} & \end{array}$


Distribution

Truck

Share: $\quad 100 \% \quad$ see report

Distance: $\quad 30 \mathrm{mi} \quad$ see report

Butanol Combustion in Vehicles

On-Road Fuel Economy:

$24.5 \mathrm{mi} / \mathrm{gal} \quad$ see report

A2 PARAMETERS FOR PETROLEUM-BASED ACETONE ANALYSIS

Energy Use

Energy Used as Process Fuel

Electricity: $\quad 0.31 \mathrm{kWh} / \mathrm{kg}$ acetone $\quad$ see report

Oil: $\quad 9,337 \mathrm{Btu} / \mathrm{kg}$ acetone see report

NG: $\quad 10,678 \mathrm{Btu} / \mathrm{kg}$ acetone see report

Energy Used as Feedstock

Oil: $\quad 12,961 \mathrm{kWh} / \mathrm{kg}$ acetone see report

NG: $\quad 18,908 \mathrm{kWh} / \mathrm{kg}$ acetone see report

Cumene Transportation

Truck

Share: $\quad 100 \%$

Distance: $\quad 323 \mathrm{mi}$ see report

Fuel economy: $\quad 5.0 \mathrm{mi} / \mathrm{gal}$ see report

\section{A3 TRANSPORTATION FOR CORN-ACETONE}

Rail

Share: $\quad 100 \% \quad$ see report

Distance: $\quad 500 \mathrm{mi}$ see report

Truck

Share: $\quad 100 \% \quad$ see report

Distance: $\quad 100 \mathrm{mi}$ see report

\section{A4 FUEL SPECIFICATIONS}

\section{Butanol}

Low heating value $\quad 99,837 \mathrm{Btu} / \mathrm{gal}$

Density 3,065 g/gal

Carbon content $\quad 65 \%$

Acetone

Low heating value $\quad 83,127 \mathrm{Btu} / \mathrm{gal}$

Density 2,964 g/gal

Carbon content $\quad 62 \%$ 
Argonne

Energy Systems Division

Argonne National Laboratory

9700 South Cass Avenue, Bldg. 362

Argonne, IL 60439-4815

www.anl.gov

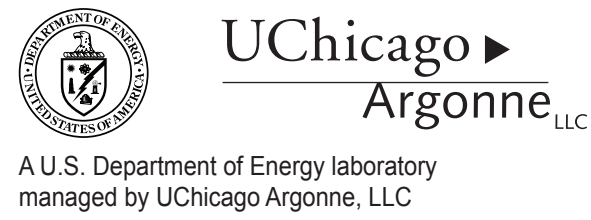

